\title{
Smallpox and the Baiame Waganna of Wellington Valley, New South Wales, I829-I840: The Earliest Nativist Movement in Aboriginal Australia
}

\author{
Hilary M. Carey and David Roberts, \\ University of Newcastle, NSW, Australia
}

\begin{abstract}
Of all the various infections that afflicted Aboriginal people in Australia during the years of first contact with Europeans, smallpox was the most disastrous. The physical and social impacts of the disease are well known. This article considers another effect of the contagion. It is argued that a nativist movement in the form of a waganna (dance ritual) associated with the Wiradjuri spirit Baiame and his adversary Tharrawiirgal was linked to the aftermath of the disease as it was experienced at the settlement site of the Wellington Valley of New South Wales (NSw). The discovery of this movement is of considerable significance for an understanding of Aboriginal responses to colonization in southeastern Australia. It is the earliest well-attested nativist movement in Australian ethnohistory.
\end{abstract}

\section{Introduction: Smallpox and Australian Aborigines}

For much of the past five hundred years, smallpox has reigned as one of the greatest killers on the planet. Yet with the elimination of the last known pockets of the disease, announced by the World Health Organization in May 1980 and the World Health Assembly resolution of May 1999, which reaffirmed the 1996 decision to destroy the remaining stocks of variola virus, it may well be that only historians will have an interest in the disease in the future. ${ }^{1}$ This essay attempts to provide an analysis of one response to the demographic crisis sparked initially by smallpox among the Wiradjuri people of southeastern Australia. As in native North America, the evaluation of the impact of the disease has been controversial, particularly when ethnohistorians have attempted to assess the impact of epidemics on precontact societies. ${ }^{2}$ But there seems little doubt that of the various infections that afflicted Aboriginal people in the contact era, smallpox was the most devastating.

Ethnohistory 49:4 (fall 2002)

Copyright (c) by the American Society for Ethnohistory. 
In the first fifty years of European occupation of Australia, there were at least two major epidemics of smallpox among the Aboriginal population. This article is mainly concerned with the second epidemic of I 829-3I, which came just forty years after the first that was witnessed by members of the First Fleet around Sydney Cove in 1789 . The second epidemic coincided with the beginning of a dramatic expansion of the pastoral frontier into the lands of the Wiradjuri, the Kamilaroi, and other peoples of the southeastern interior of New South Wales (NSw). ${ }^{3}$ The source and degree of severity of the earliest epidemics have been regular points of debate in Australia, no less than in the Americas. There has been speculation since at least I950 that the disease arose as a consequence of contact with "Macassan" visitors to the north coast of Australia. ${ }^{4}$ This theory is supported by the weight of contemporary evidence, as demonstrated by Judy Campbell and by Alan Frost, though some historians have been slow to shed suspicions that the disease was deliberately introduced by Europeans. ${ }^{5}$ For example, in a lively exchange published in the conservative Australian periodical Quadrant in 1985, Noel Butlin was accused of overdramatizing the possibility that the original epidemic may have been deliberately (or accidentally) introduced by Europeans. ${ }^{6}$

The smallpox epidemic initiated a period of intense cultural disorientation for the native people of Nsw during which the direct impact of the disease was compounded by the effects of European colonization, military action, and losses from other introduced diseases, especially influenza. ${ }^{7}$ This much seems certain. But although scholars have made some investigation of the demographic impact of smallpox and other diseases on Aboriginal populations in southeastern Australia, very little has been attempted in the way of analysis of the deeper intellectual and cultural responses of Aboriginal people to match studies of other indigenous frontiers, such as in North America. ${ }^{8}$ In both Africa and India, where smallpox has a longer history and lacked the overwhelming virulence it possessed when encountering indigenous populations in the New World, there was cultural space for the development of religious strategies to avert the spirit forces responsible for the disease. ${ }^{9}$ In Aboriginal Australia, there was little time for this, but evidence is presented here that the epidemic precipitated the development of a traveling cult in Wiradjuri country that reflected deep hostility to both the presence of Europeans and the diseases associated with them.

In 1836 , the English missionary William Watson wrote dismissively in his annual report to the Church Missionary Society about the religious life of the Wiradjuri people in whose country he was conducting a mission:

The only kind of worship known among them is the Waggana or native dance accompanied by singing to Baiamai who annually, about Febru- 
ary or March, reveals to some one native, at a very great distance from Wellington, "the Song" in which all are bound to join under penalty of death. This Song is esteemed sacred by the natives, who apprehend that if they should not be present at the singing of it they would die..$^{10}$

Although it was traditional in form, the Baiame waganna (dance) described here by Watson can best be described as a "nativist" or "revitalist" movement. ${ }^{11}$ Both of these terms need to be defined with care. However, they reflect the twin objectives of the cult that sought to revitalize traditional society by averting smallpox and preventing Aboriginal women from consorting with European men, as well as reviving native practices such as murru gian, or the piercing of the septum to allow a bone to be worn through the nose. It thus appears to be the earliest nativist movement that has been detected among the Australian Aborigines, a people who have been reported to lack significant movements of this type. ${ }^{12}$

It will be argued that the Baiame waganna provides evidence for change in the perception of local religious beings, including Baiame himself and the spirit said to be responsible for the bringing of smallpox, Tharrawiirgal. The origins and meanings of the All-Fathers or High Gods of southeastern Australia have been the subject of repeated investigation by scholars since the mid-nineteenth century. ${ }^{13}$ Anthropologists have long voiced the suspicion the All-Fathers arose in response to syncretist pressure following contact with missionary teaching. The most controversial account has been that provided by Tony Swain, who has argued that the AllFathers and their dualist mythological baggage are the product of colonial contact, possibly of some vaguely defined millennial or cargoist variety. ${ }^{14}$ Swain's views on the All-Fathers have not been generally accepted; his thesis has been discounted on the grounds that it requires too much change, too quickly, from the Aboriginal cultures of the southeast. ${ }^{15}$ In addition, it is clear from a more careful examination of the historical and ethnographical evidence, including the unpublished journals of the Wellington Valley missionaries (to which Swain does not refer), that some of his conclusions arise from a conflation of European accounts of two quite separate ritual activities in Wellington, namely, the traditional ceremony of initiation, over which Baiame was said by later informants to preside, and a new ceremony to Baiame that would strengthen the Wiradjuri against smallpox and the Europeans who preyed on their women. ${ }^{16}$ The interpretation provides some of the missing historical substantiation for Swain's intuitive leaps of argument in favor of a rapid transformation of Aboriginal ontology in the southeast, including a magnification of the powers of the All-Fathers.

Beyond the identification of the waganna as a traveling cult, interpretation is hampered by the lack of accepted models for cultural change 
and adaptation to colonization in Aboriginal society. Traditional concepts of religious adjustment, such as nativism and revivalism, as well as cargoism and millenarianism, have generally been assumed not to apply to Australia. ${ }^{17}$ Standard reference works support the consensus view that Aboriginal society is characterized by a failure to generate new religious movements, in marked contrast to Melanesia, which maintains a reputation for the profligate generation of movements of this type ${ }^{18}$ Hence, Erich Kolig asserts that Aboriginal society shows a "total absence (with some exceptions)" of those charismatic, messianic, millenarian, and prophetic movements spawned elsewhere under the impact of colonialism..$^{19}$ Kolig nevertheless goes on to provide accounts of nine well-documented movements, covering most parts of Australia, that were recorded by anthropologists in the brief period from the beginning of significant professional fieldwork in the I930s to the I970s. He also includes two cults observed by A. W. Howitt in the southeast in the late nineteenth century. Klaus-Peter Koepping, who provides the most careful theoretical account of Australian "nativistic movements," also begins with the assumption that such movements are rare in Australia, but he also notes that no people choose to remain silent under the burden of colonial oppression and that the Australian Aborigines form no exception to this rule. ${ }^{20}$ The Baiame waganna would seem to provide support for the force of this statement and also for the need for ethnohistorians to pay closer attention to surviving missionary records when seeking evidence for religious change in Aboriginal societies. While Koepping, for example, accuses missionaries of "intentionally ignoring new cult activities in aboriginal society," it is also true that ethnographers have ignored the potential of missionary writing as a source for indigenous belief. ${ }^{21}$

\section{The Frontier at Wellington}

In the I820s and I830s, Wellington Valley was on the outermost fringes of the European frontier in Australia, then commonly known as New Holland $^{22}$ (see Figure I). From I823 it was the site of convict agricultural and stock establishments, ordered by the colonial authorities to secure a state presence in the remote west of NSW ahead of a burgeoning private grazing frontier. ${ }^{23}$ For several years the settlement was the most remote sphere of public enterprise west of Sydney, a relatively unproductive and costly exercise that lingered long after it was pronounced to possess "no advantages" to offset the "inconvenience and expense" of its maintenance. ${ }^{24}$ After the government establishments were withdrawn in I830-I, the abandoned buildings were taken over by the NSw auxiliary of the Church Missionary 


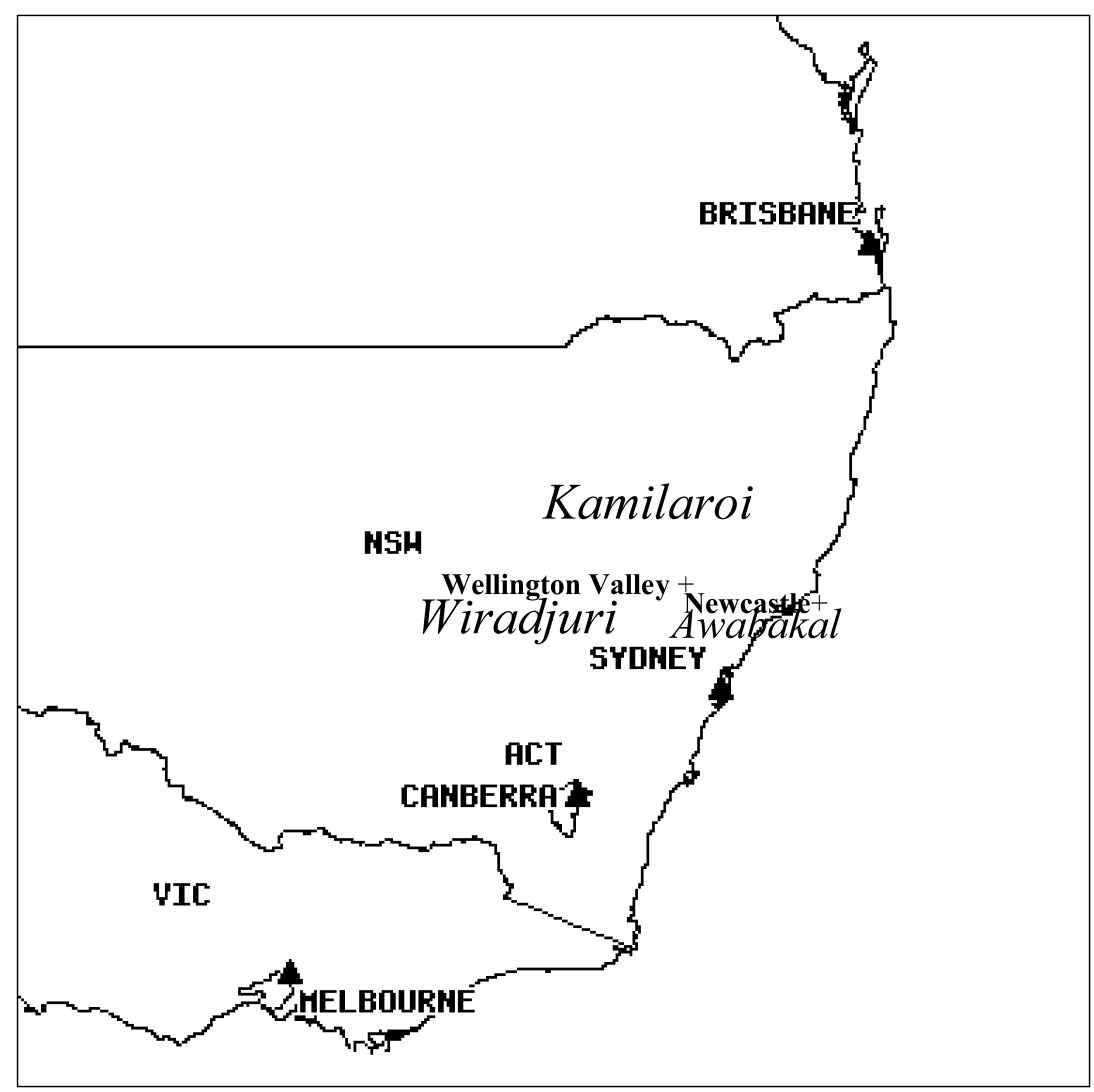

Figure I. Map of localities and tribal areas (in italics) referred to in the text. Distances are not to scale. Map by Geoscience Australia.

Society for the state-sponsored mission to the Aborigines. During this time, the settlement and its environs accommodated a mostly itinerant and transitory frontier population of settlers, shepherds, soldiers, and policemen.

This period saw a rapid escalation in the degree and extent of pastoral settlement west of the Great Dividing Range, emanating from the central villages at Bathurst, immediately west of Sydney. This brought the colonists into contact and conflict with part of an extensive and diverse Aboriginal nation, the Wiradjuri, whose territory comprised a great range of geographic subregions across most of central-western NSW. ${ }^{25} \mathrm{~A}$ tenacious and resilient people, the Wiradjuri have survived almost two centuries of repressive dispersal and assimilation policies enacted and reenacted by 
successive generations of white administrators. ${ }^{26}$ Their experiences, however, remained peripheral to the popular/public historical imagination of white Australians until the I970s, when a critical generation of historians, pioneered by Henry Reynolds, began measuring the impact of European colonization and the Aboriginal responses to invasion from "the other side of the frontier." ${ }^{27}$ Initially the focus was on settler violence and Aboriginal resistance, chronicling the forgotten conflict of the Australian frontier. The historiography has been tempered and elaborated by insightful works examining nonviolent resistance and emphasizing themes of accommodation, adaptation, conciliation, and mutual dependence. ${ }^{28}$ Fewer historians have followed Beverly Nance's pursuit of the internal impact on Aboriginal society by considering the adjustment of traditional beliefs and customs consequent to contact with Europeans. ${ }^{29}$

At Wellington Valley, the meeting of settlers and Aborigines did not produce the violence and lawlessness that Reynolds posited as an "inescapable feature" of the contact experience in Australia. During the early I820s, as a consequence of the rapid expansion of European settlement in the Bathurst region, there were sporadic clashes between Aborigines and settlers that culminated in 1824 , when the western district was placed under martial law, one of only two occasions when martial law was evoked to deal with interracial violence in the Australian colonies. There were serious affrays on the Cudgegong River, northwest of Wellington Valley, and to the south around Orange. At the height of the crisis, it was observed that while "Bathurst with its surrounding vicinity is engaged in an exterminating war, peace reigns around the ever verdant Valley of Wellington." Aborigines with gunshot wounds came to the Wellington settlement for medical assistance..$^{30}$ The varied accounts of commandants, missionaries, settlers, and travelers unanimously describe the Wellington Wiradjuri as a peaceable and accommodating people, "rather delighted" ${ }^{31}$ by the opportunity for trade and material acquisition and adept at taking advantage of Europeans. They displayed an exemplary capacity to adopt new skills and foreign technologies, and their cooperation and labor was critical to the fledgling local pastoral economy. But although there is no evidence, as there is in the New World, of disease being deliberately spread and otherwise affecting the conduct of frontier hostilities, ${ }^{32}$ Europeans posed serious social and cultural challenges to Wiradjuri society. Wiradjuri responses to their rapidly changing world were obliged to develop in the context of a calamitous demographic decline that critically damaged the power and efficacy of their traditional cultural resources. The most significant of the demographic challenges faced by the Wiradjuri was that posed by smallpox. 


\section{The Smallpox Epidemic at Wellington Valley}

The smallpox epidemic reached the central west of NSw during I830, a year after the explorers Charles Sturt and Hamilton Hume encountered Aborigines with unpleasant skin disease and blindness on the Darling River, northwest of Wellington. ${ }^{33}$ Reports of a serious native epidemic in the districts around Bathurst circulated for some time before they roused the attention of medical gentlemen in Sydney, such as Staff Assistant Surgeon Alexander Imlay, who went to Wallerawang (Lithgow) to make observations in September I83I. Imlay's representations led to the government commissioning an investigation, though it was probably most swayed by emerging reports of Europeans being infected. ${ }^{34}$ The task was given to Dr. John Mair, assistant surgeon, Thirty-ninth Regiment, who went to Bathurst in October I83I. Mair is the chief authority for the immediate impact of the epidemic, though the value of his observations is seriously limited. He did not travel to the outer districts, preferring to gather reports from various local sources. These included the notorious George "the Barber" Clarke, a runaway convict recently captured by the mounted police after a sojourn of several years among the Kamilaroi. Moreover, by the time Mair went to Bathurst in early October I83I, the crisis had passed: "The disease had finished its work of desolation and left only its traces behind," he wrote in his report to the colonial authorities. ${ }^{35}$

The smallpox epidemic reached Wellington Valley shortly before the final closure of the government station when Superintendent James Kinghorne was busy reassigning convicts and transferring stores and stock to Bathurst. Given this situation, it is probably not surprising that his papers do not allude to the dreadful fate of those native men, women, and children who had only recently congregated on the settlement to receive government blankets. ${ }^{36}$ Despite Kinghorne's oversight, there is some evidence that the disease was particularly savage in its impact in the Wellington area. In the reports of I83I, Wellington was singled out as one of a couple of locations where the epidemic had been most destructive. Mair estimated that the mortality rate varied between 16 and 33 percent of the population, a figure he attributed partially to the lack of care and shelter available to the sufferers. At Wellington, however, it struck down the Aborigines "numerously and almost without exception." ${ }^{37}$

The chancy and unreliable nature of European observations of the disease and its impact on scattered Aboriginal peoples scarcely permits a more precise measurement of the demographic impact of the epidemic than Mair's vague estimations. However, in the absence of other methods of calculating the local population, the demographic impact of smallpox can 
Table I. The Wellington Wiradjuri, 1835

\begin{tabular}{lccc}
\hline Designation of "tribe" & $\begin{array}{c}\text { Number } \\
\text { of men }\end{array}$ & "Wives" & Children \\
\hline "Wellington" or "Wellington Valley" & 40 & N/A & N/A \\
$\quad$ (includes "Goboleon," "Narragaul," & & & \\
$\quad$ and "Newrea") & 1 & & \\
"Baddah" & 4 & & \\
"Birdthiree" & 7 & & \\
"Boree" & 6 & & \\
"Burrandong" & 1 & & \\
"Minore" & 1 & & 23 \\
"Mudgee" & 10 & & \\
"Murrambirdthre" & 70 & 60 & \\
Total (N =153) & & & \\
\hline
\end{tabular}

Note: Age distribution of men: 50+: 6; 40-49: I7; 30-39: II; 20-29: 24; I6-I9: I2. Source: Reverend William Watson, "Return of Aboriginal Natives Taken at Wellington Valley, I834," to Col. Sec., 29 January I835, CSIL 35/1068, SRNSw 6/6666b.

be calculated roughly by using the annual returns of blankets distributed to Aborigines. Prior to the I840s, the blanket returns were the only statistical account of Aboriginal society kept by the colonial authorities. It was a crude, piecemeal census that was used by humanitarians to assess the decline of Aboriginal populations in Nsw and back up their calls for reform. ${ }^{38}$ The Wellington Valley returns were compiled by the superintendents of the government station between 1827 and I830 before the epidemic had struck. At this time it was considered "impossible to collect them together at any one time," but the superintendents still managed to count up to 138 local men and some of their women and children..$^{39}$ The superintendents' returns are not easily compared with the postepidemic records kept by the missionaries of the Church Missionary Society, who took over the local blanket distribution when they arrived in $\mathrm{I} 832$. The missionaries could name more than 150 local Aborigines, but this number may have included a wider group of people than those who were in contact with the convict station in the I820s. The list compiled by Watson in I835, summarized in Table I, provides an account of 70 men, including their 60 "wives" and 23 children, a total of 153 people. However, only 40 of the 70 named men were from the immediate Wellington Valley group. ${ }^{40}$ The wider body of mission records suggests that during the i830s, when the Wellington Aborigines were apparently more disposed to assemble on European stations such as the mission, the only large gatherings were those associated 
with major ceremonies, such as initiations or the Baiame waganna, which always included a significant number of outsiders. ${ }^{41}$ It would appear on this basis that Mair's report was, perhaps, only slightly exaggerated and that the local Wellington population fell by up to a third, largely as a result of this one epidemic. ${ }^{42}$ It is probably more significant for the final fate of the Wiradjuri that the decline was not arrested by the birth and survival of new children, who form an alarmingly low proportion of all counts from whatever source. ${ }^{43}$ By the time James Günther arrived at the mission on 8 August I837, the population seems to have entered a fatal spin from which it was never to recover ${ }^{44}$ It is important to recognize that the epidemic on its own was not sufficient to subdue the Wiradjuri but that their fertility was fatally compromised by the combined effect of subsequent and simultaneous infections, such as influenza and measles, as well as venereal diseases, infanticide, and hunger, all of which are reported by the missionaries. ${ }^{45}$

One qualitative measure of the impact of the disease is the absence, in the journals of the missionaries who arrived in October I832, of the names of men and women, young and old, who had come to the convict settlement in previous years to collect government blankets and spoiled beef. Many do not appear in any records after the blanket distribution of July I830, and it has to be assumed that these people were victims of the epidemic. Another piece of evidence is the number of orphaned children encountered by the missionaries, such as the "little interesting girl . . . the most intelligent looking female I have seen among the Blacks," found by Watson's junior missionary, Rev. Johann Handt, at a station where she had been residing with the hut keeper since she buried her parents who had died of smallpox two years earlier. ${ }^{46}$ The surviving adult population included men such as Kobohn Bobby (or Woowah, Blind Bobby), the "King of Burrendong," a tall, stout man who had lost his sight because of smallpox. ${ }^{47}$ There was also Mooinba (Gentleman Jackey), who emerged as a survivor of the disease to lead the Baiame waganna, which had, as one of its objectives, the prevention of smallpox's return.

\section{Aboriginal Responses to the Epidemic}

It is now recognized that even before large-scale European settlement occurred in the southeast, the impact of disease and frontier violence had led to significant shifts in the patterns of life and belief of Aboriginal people. All ethnography of this vast area, including classic large-scale studies, such as those of A. W. Howitt and R. H. Mathews at the turn of and Ronald M. Berndt in the twentieth century, record the memory and transitional culture of a people in retreat. ${ }^{48}$ The response to the epidemic of $1829-3 \mathrm{I}$ 
as recorded by settlers, travelers, and missionaries in the 1830 s therefore provides a window through which the process of cultural innovation and readjustment can be observed.

After the first period of panic and mourning, the Wiradjuri apparently began to search for the meaning of the epidemic from within the resources of their traditional culture. From what causes had the disease that they called thunna thunna arisen? ${ }^{49}$ To explain and possibly control so virulent a misfortune, the Wiradjuri appear to have employed a wide range of explanatory frameworks, natural and/or magical, indigenous and/or borrowed. In the southeast of Australia, traditional Aboriginal causes of death were nearly always understood to be associated in some way with the operation of sorcery or magic, for which some individual was necessarily responsible, although the agent might be a spirit force..$^{50}$ The arrival of European disease and violence could lead to a rise in sorcery accusations and revenge killings between rival Aboriginal communities. ${ }^{51}$ But according to George Bennett, citing Mair and his informants, the Aborigines at Wellington blamed the appearance of the disease on Captain Sturt. ${ }^{52}$ On this evidence, Campbell suggests that in areas that attracted rapid settlement, such as the fertile pastoral land of the southwest, "Aboriginal beliefs in sorcery predisposed them to blame the whites for the sickness and deaths." 53 If Mair's informant was correct, however, they were not blaming Europeans in general, but Sturt specifically, for the Wellington Aborigines had been among Europeans for more than ten years. ${ }^{54}$ Mair was contradicted by Bennett, who understood that "the aborigines at Wellington Valley ... did not regard it as of foreign introduction." ${ }^{55}$ Dr. George Busby, medical officer at Bathurst, remarked that the Wellington Aborigines had spoken of the disease long before it actually appeared there, "and they regarded its approach with dread." 56

Unfortunately there are few accounts of Aboriginal beliefs in Wiradjuri country that predate the second smallpox epidemic of $\mathrm{I} 829 .{ }^{57}$ Indeed, the problems of securing information about Aboriginal rituals and religious practices are even more acute than those associated with demographic issues. The earliest account on which some reliance can be placed was written by the geologist John Henderson after his visit to Wellington in July I830. Henderson's Observations on the Colonies of New South Wales and Van Diemen's Land, published two years after his stay in the field, ${ }^{58}$ provides the first European description of the deity he called Paime (Baiame), whom he named "the god of the black people of New South Wales" and "the father of their race." Henderson also refers to Baiame's adversary, Mudjegong, which "seemed to be described under the form of the eaglehawk." ${ }^{59}$ In accounts a few years later by missionaries, the adversary of 
Baiame is named consistently as Tharrawiirgal. It is Tharrawiirgal in these later versions who is said to have been responsible for the smallpox epidemic. Henderson refers neither to Tharrawiirgal nor to the epidemic, but he does provide a detailed account of what appears to be the Wellington burbung (male initiation ceremony), naming as his informant a traditional "doctor" or clever man called Marinbilly, whose picture is included on the frontispiece of Henderson's book. Henderson also suggests that Baiame had some of the characteristics of a returning culture hero. He was a mighty spirit who had once rolled over and flooded the land, but he was expected to come back "at some distant period," although he was currently asleep, and on that day he would bring about a similar disaster.

Other millennial beliefs, sometimes incorporating ritual elements, were reported elsewhere in southeastern Australia, and they also figure in reports from the Wellington area. ${ }^{60}$ In I83I, Bennett noted that the Wellington blacks considered that the epidemic must presage some terrible calamity: "A great fire and flood were predicted by one of their sages, which would come from Mount Harris and destroy them." ${ }_{61}$ The vagueness of these predictions is tantalizing, but it seems likely that they were not linked to a wider mythic vision of the end. There is sporadic evidence that one cultural response that was made to the epidemic was the creation of new dance rituals and mourning ceremonies. In I830, Bennett reported on a "most lugubrious dirge" chanted at an Aboriginal ceremony in Bathurst, which he judged to be related to smallpox "from the melancholy note and solemn manner of the pageant." ${ }^{62}$ Smallpox would seem to have already invited a special cultural response.

\section{The Baiame Waganna, $1833-5$}

Two to three years after the epidemic had first struck, these tentative responses seem to have been elaborated into a waganna or dance ritual that can best be seen as a nativist movement. There is a reasonably complete account of the waganna in the unpublished journals maintained by two of the four men employed by the Church Missionary Society to run a mission in the Wellington Valley of NSW from I832 until the collapse of the mission in $1840.6^{63}$ Although historians have known of these journals for some time, they have not been employed before now for their ethnohistorical content but rather for the history of Aboriginal colonization and attempted conversion. ${ }^{64}$ In addition, it would be fair to note that most historians have neglected the journals of Watson and Handt (which are nevertheless available in Australia on microfilm) in favor of the more accessible papers of their fellow missionary at Wellington, James Günther, original 
copies of which are held in Sydney's Mitchell Library ${ }^{65}$ The account that follows is based principally on the journals and correspondence of Watson and Handt, and only occasionally those of Günther, who arrived at the mission after performances of the Baiame waganna had ceased. ${ }^{66}$ Transcripts of key passages are reproduced in the Appendix. Comparison of these extracts with the complete transcript of the missionary journals, which is an ongoing project of the authors, ${ }^{67}$ makes it clear that the missionaries only rarely included information about Aboriginal beliefs in the course of preparing their journals for report to the Church Missionary Society, and it would appear that only the junior missionary, Handt, attended any ceremonies in person.

It is important to recognize the strengths and limitations of the ethnographic information provided by mission sources for Aboriginal ritual activity. At Wellington, the missionaries were well placed to be authorities after living in close contact with the Wiradjuri for three years. But they had not so mastered the local language and culture as to be capable of understanding the subtleties of a complex and changing religion, particularly one so foreign to their own evangelical Anglicanism as that of the Wiradjuri. In this respect the missionaries were no different from other European observers, most of whom had little understanding of cultural changes on the frontier and provided no commentary on what was happening to the Aboriginal peoples with whom they came in contact beyond those exchanges that involved violence or sex. In many cases the missionaries appear to have had the advantage of being able to receive secret or confidential information from the more linguistically accomplished young men who worked at the mission and also attended major rituals. But the missionaries were not specialized, sympathetic anthropologists, and therefore all their reports must be filtered through the grid of their own incomprehension and hostility to most native beliefs and practices. Nonetheless, these missionary journals provide a unique source of contemporary observation of Wiradjuri ceremonial culture in the I830s, and over time the missionaries appear to have become increasingly sympathetic and interested observers of the activities that took place at the camps and stations surrounding the mission house. To these observations, we now turn for an account of the Baiame waganna of $1833^{-5}$.

In 1833 , Watson reported that a "corrobora ... respecting Thannah Thannab (the smallpox)" was held in early October, which, as usual, he did not attend. ${ }^{68}$ It was a solemn occasion and seems to have been regarded as an effective prophylactic against the disease. Watson was told, presumably as a result of the ceremony, that "it will never come here again." The ceremony was on a small scale, attended by only five or six men from the 
mission, including one boy who was seriously beaten after reproving one of the older men for swearing. It might be noted here that one characteristic of smallpox was that a single infection conferred life-long immunity. Rituals performed by a community that had been hard hit by infection were likely to be perceived as efficacious, as the disease appeared to submit to ritual precautions, declining in frequency and virulence before disappearing - for the time being.

Over the next two years the ceremony that the missionaries called a corrobborree $^{69}$ or waganna to Baiame was held on a regular basis in the Wellington area, with the performances gradually building in intensity and ritual elaboration. As European settlement proceeded, the mission became a staging post for a dramatic reconstruction of the Wiradjuri world order in which Baiame would bring Europeans under his control, just as he controlled the hostile impulses of his adversary, Tharrawiirgal. The ceremony appears to have been connected with a series of rumors and prophecies that rattled around the mission house in these years. Some of these appear to have derived at least partially from mission teachings. In April I834, Watson reported that the natives "have got the idea that the world is shortly to be partially destroy'd by a flood." Those who were to survive must build a "large hut" in which all kinds of animals would enter of their own accord. The prophecy came from "one celebrated Native who lives near to a large river." ${ }^{70}$ Despite the close parallels to the biblical narrative of Noah's Flood (Gen. 6-9), the missionaries were not pleased. Nevertheless, when the missionaries attempted to denigrate the prophecy, their objections were met with disdain. Watson goes on to note: "They use no arguments and they appear to be exceedingly angry if the truth of what they relate is disputed." 71

The Baiame waganna needs to be distinguished from the usual cycle of ceremonies such as the Wiradjuri burbung, which continued to be attended by young men from the mission despite the disapproval of the missionaries. ${ }^{72}$ In May 1834, for example, both Handt and Watson reported that a dance was held a few miles away from the mission station that they were powerless to stop the young men of the mission station from attending. There is no description of the purpose of the ceremony except that it led to the infection of one of the young men of the mission with venereal disease. ${ }^{73}$ In December I834, another large ceremony was held about ten miles from the mission at Gobolyen station, the site of a major ceremonial ground. ${ }^{74}$ On this occasion, Handt counted ninety-six people and reckoned it to be one of the largest parties he had ever seen in Wellington. ${ }^{75}$ Here it might be worth noting that the willingness of the missionaries and other European stock station proprietors to distribute food to parties of Aborigines 
is likely to have enabled them to gather in larger numbers for ceremonial purposes than might have been possible before Europeans and their cattle and stores arrived. ${ }^{76}$ The missionaries also recognized that the availability of steel tools allowed for a much more rapid and extensive development of the groves of dendroglyphs, or trees carved with totemic patterns, sand sculptures, and spaces cleared of vegetation that formed the stages for ceremonial occasions, than had been possible with stone implements. ${ }^{77}$

During the first few months of 1835 , the missionaries reported on the buildup to a major ceremonial cycle whose significance they never seem to have fully grasped except to recognize that it was qualitatively different from anything they had observed before. In his later account, Günther noted that the ceremony involved the gathering of distant tribes and that it took many months for them all to assemble for the occasion. ${ }^{78}$ Such exchanges, which were a common feature of other major ceremonies including initiations and funerals, were an indication of the importance of the ritual. ${ }^{79}$ In early February, Aborigines were reported to be gathering around Wellington, including a party of thirty, who camped near the mission house. The missionaries were pleased that divine service was well attended..$^{80}$ On 23 February, however, the Aborigines left the mission and there were reports of a "strong mustering" twenty miles away. Watson was frustrated that he was unable to follow them on account of a "severely scalded" foot. ${ }^{81}$ In late February and early March, however, the mission was not visited by a single Aborigine..$^{82}$ In the last week of March and early April, even Aborigines who normally resided with Watson and Handt, such as Goongeen, were drawn away from the mission for reasons the missionaries did not, or were unable to, explain. Handt reported that a young boy he was teaching was enticed away by his father and that other boys from neighboring stock stations were also said to be making their departure. ${ }^{83}$

Women seem to have been more reluctant to take the traditional place allocated to them in major rituals. However, they began to be brought to order toward the end of March. ${ }^{84}$ In a letter to the Church Missionary Society (CMS) secretary in Sydney dated 25 March I835, Watson reported that the men had been actively taking their women and children away from all the stations in order to assemble at a "general Corobbera to Byamy." While recent ethnography has stressed the complementary authority of Aboriginal women in spiritual matters, this was not the perception of the missionaries at Wellington. Indeed, the new ritual appears to have had as one of its purposes a renewed insistence on the authority of Wiradjuri men over their women, backed by the anger of Baiame himself: "They say white man stole Byamy's wife and he is going to kill all white man, and all the natives that are found with them." ${ }^{85}$ On 28 March, Watson recorded a 
renewed focus on women and girls, stating that Byamy (Baiame) intended to "kill all the girls and women who live with white men." As a result of this threat, he noted that not a single female native was residing at any station for miles around. There was a similarly ferocious injunction that all the natives must attend the ceremony to Baiame or they would all be killed. ${ }^{86}$ In the same journal entry, Watson linked the Baiame waganna to earlier anti-European prophecies that Baiame was "about to kill all the Europeans in this country because someone had seduced his wife." But on ro April, Watson reported that the god's anger was directed not at Europeans but at natives whom he would destroy if they "lived with Europeans, lend their females or children to them, or failed to celebrate this Waganna." Here the ceremony would seem to have some of the character of the best-known nineteenth-century nativist movement, the Mulunga cult, which was similarly anti-European and revivalist, asserting the importance of the vigorous maintenance of customary law in relation to ritual and custom, especially marriage and sexual relations. ${ }^{87}$

The culmination of this sequence of events occurred over a series of nights early in April I835, shortly before the solemn Christian feast of the Crucifixion, which Watson noted in his journal on 17 April. For the first time, Watson set aside his habitual reluctance to refer in any detail to native religious beliefs and provided a lengthy description of the Baiame waganna and the local deities, Baiame, Tharrawiirgal, and Burambin, as well as the role of the leader of the ritual, Gentleman Jackey. ${ }^{88}$ We have little information on the actual performance and content of the waganna or the gudthi (song) that was its central inspiration. According to Watson, the ceremony was held at a place called Babydyal (land of nettles) and involved a song that had been "made by Byamy" and "sent by a Lizard from who it was communicated to some Natives." ${ }^{89}$ It is reasonably clear from the missionaries' account that the song came into the Wellington area from some distance away. Watson thought that it was composed in some literary dialect that defeated his small powers in the native language. ${ }^{90}$ However, Günther, whose knowledge of the song was derived from reports entrusted to him confidentially by participants, was more likely to be correct in his assumption that the song was not composed in Wiradjuri but a language to which it was only distantly related..$^{91}$ We are fortunate to have Watson's grudging description of the song, which was probably translated for him by one of the trusted young men of the mission, but his description is terse, noting merely that the song was "very short," involved the beating of sticks, and concerned "something respecting angels; carrying on the back; playing to him; and throwing into the fire." 92

It was in the ritual itself that the practitioners appear to have sought 
protection from smallpox. According to Watson, Baiame had commanded that they use small sticks, called mudthir, to beat themselves with during the dance and afterward throw into the fire. ${ }^{93}$ It is possible that the beating may have been intended to emulate the pustules and scarring of the disease, and the destruction of the sticks, the aversion of death. Bennett provides descriptions of various forms of treatment of smallpox by traditional healers, including the use of a crystal as well as pricking or scratching pustules with fish bones. ${ }^{94}$ The therapeutic pricking of pustules by the clever man may also be reflected in the pricking and beating of the waganna. Like the prophet movements of the Plains peoples of North America, the Baiame waganna apparently had, as one of its aims, the fortification of the faithful against demographic collapse. ${ }^{95}$

Prophet leaders are briefly sighted in the generally hostile records of the Wellington missionaries. They include figures such as Kabbarrin, who tells Watson that a shooting star was indicative of a departing spirit or the premonition of such..$^{96}$ Also active is a senior Wiradjuri man, Lord Grey, who sometimes preached the Christian message to the people in the camps to the mixed delight and suspicion of the missionaries. But the most significant prophet appears to have been a man called Mooinba, who was known to the missionaries as Gentleman Jackey. ${ }^{97}$ During the late I820s, Gentleman Jackey was one of about thirty-five Aboriginal men identified by the authorities as belonging to the "Binjung," the term for the local Wellington clan. In 1829 , his name was high on a list of Aboriginal men receiving blankets from the stores at the Wellington settlement. Although clearly a local man of high status, he did not associate closely with the missionaries after their arrival in the valley, but he was able to manipulate them for certain purposes of his own. In I8 32 and I833, the missionaries had been obliged to travel long distances throughout the bush to locate subjects for evangelization. But by 1835 Handt wrote that it was "discouraging" to plan trips into the bush knowing that blacks were only to be found at stock stations, where they could find food in return for prostituting their wives to Europeans. ${ }^{98}$ Following this model, Gentleman Jackey seems to have used the mission house as a base for operations involving the distribution of his six wives and the organization of the Baiame waganna. The missionaries do not speculate on the factors that gave him his authority, but it may be related to his apparent immunity to smallpox. In contrast to his countrymen, ravaged by the mutilations of the epidemic as much as traditional scarification, Gentleman Jackey was a fine looking man, about thirty-five years of age and, according to Watson, "more free from disease than any other I have known of his age." ${ }^{99}$ For whatever reason, he was able to prosper in the wake of the epidemic, collecting many wives and actively seeking 
more - to the horror of the missionaries. It is an indication of the demographic fragility of the population that, despite his six wives, Gentleman Jackey appears to have had no children.

At the height of the Baiame waganna, however, disaster struck. Watson wrote in his journal for 6 April: "Intelligence has reached us that Gentleman Jackey is dead. This is a circumstance that may affect the minds of some of the Natives." ${ }^{100}$ Gentleman Jackey was seized with a violent pain in the heart in the midst of the waganna and died some two days later. Nevertheless, it seems likely that the cycle of ceremonies was not too much disrupted on this occasion because Handt and Watson note that additional performances - or further installments of the same performancewere held over two weeks later, on 23 or 24 April I835 and again on 8 May. ${ }^{101}$ On 24 May, the Aborigines were anxious that the missionaries attend, sending them fire sticks to summon them and light their way. Although Handt provides an account of what he saw, he shows little understanding of what the ceremony might mean, commenting: "I could not help pitying them, because they will not taste the better pleasures of religion, and of communion with God." 102 Watson's intimation that the death of Gentleman Jackey, who was both a major devotee of the cult and probably a powerful Wiradjuri native-doctor, might have an impact on the waganna was nevertheless borne out by subsequent events. When the linguist Horatio Hale visited Wellington in I838 with the U.S. Exploring Expedition, he passed on the views of the missionaries about the rise and fall of the waganna. ${ }^{103}$ Hale noted that the dance had ceased three years earlier, in I835, when Watson wrote his first detailed comments on the dance.

Despite Hale's pronouncement, however, the cult did not disappear after the death of Gentlemen Jackey in April I835. Later in the same year, there were more prophecies circulating that may or may not be related to the Baiame waganna. In October I835, Watson noted in his journal that it was said that "there will be a general flood and all the mountains will fall down" because of the death of a man called Neddy. ${ }^{104}$ Neddy was a senior man who died at the mission, stoically refusing to respond to any of the missionary's spiritual pleading. ${ }^{105}$ Perhaps there were fears of repercussions following the break with several traditional practices noted by Watson at the time of Neddy's death and burial. After the death of Gentleman Jackey, Kabbarrin seems to have taken over the role of ritual leader at Wellington. He may also have been responsible for a shift in the focus of the waganna from the alleviation of the smallpox menace to a more central focus on the control of sexual access to Wiradjuri women and children. Kabbarrin was involved in the most elaborate theological sparring reported by Watson, magnifying the claims of Baiame against the Christian God. ${ }^{106} \mathrm{He}$ also 
disputed the missionary's right to keep women and girls of marriageable age under his protection. ${ }^{107}$

Sexual relations between European men and Aboriginal women were a major source of contention throughout the Australian frontier. According to Patricia Grimshaw, black women were "pillaged" as part of the spoils of conquest. ${ }^{108}$ However, the conditions under which Aboriginal men negotiated with European men, usually from a position of weakness, over sexual access to their women were more complex than this interpretation would imply. In the later pastoral frontier, Ann McGrath has argued that the sexual relationships were not always coerced or purely exploitative. In many cases Aboriginal women exercised some freedom to willingly enter into these relationships and frequently did so for profit, gratification, security, or freedom from rigid tribal obligations. ${ }^{109}$ In Wellington the missionaries report that, according to the Aborigines, if they failed to "lend" their women to Europeans, they would simply be taken by force. ${ }^{110}$ Although the missionaries customarily stressed the profligacy of the frontier environment as part of their campaign to limit settlement around the mission, there is no reason to doubt that sexual relations were a potentially explosive source of friction fueling the cycle that generated the prophecies and ritual of the Baiame waganna.

Besides the regulation of sexual relations between Europeans and Aboriginal women, the new prophecies insisted on a general assertion of other traditional practices. In December I835, eight months after the death of Gentleman Jackey, messengers arrived at the mission house to announce that women must continue to wear a bone through their nose and also that they should cease living with European men. ${ }^{111}$ The boring of a hole through the septum of the nose was practiced widely throughout Australia on both men and women. In southeastern Australia, according to Howitt, the practice did not have religious significance; however, given rapid cultural loss, this may not necessarily be the case. ${ }^{112}$ It seems likely that nose piercing was one of the customs that natives were pressured to relinquish in their contacts with Europeans, who found the habit disgusting. Fear of the consequences of ignoring this latest revelation was enough to make the mission women very uneasy. Some of them were reported to have attempted to pierce through their own septums with their fingernails. ${ }^{113} \mathrm{~A}$ few days later another prophecy reached the mission house; this time it was said that the soldiers were planning to "do something" with the men, taking all the women and giving them to Europeans. Resentment of European sexual control of Wiradjuri women was here openly displayed; but, as with the promised manifestation of the power of Baiame, it was to be another prophecy that went unfulfilled. In any case, there were no further prophe- 
cies after the revelation of December I835. Closure of the cycle of prophecies was achieved by the consensus, as Watson reported, that Tharrawiirgal had turned aside his anger: "The natives say that Tharrawiirgal (one of their Divinities who lives in the N.W. and who is said to be the author of the Small Pox) is not angry with them now that he will never send the Small Pox again because he has now got a Tomahawk which he formerly wanted." ${ }^{114}$

\section{Interpreting the Baiame Waganna}

The Baiame waganna, whose rise and fall can be followed in the journals of the missionaries, presents a number of challenges of interpretation, of which only two can be considered here. The first concerns the mythic significance of the reported components of the waganna: the anger of Tharrawiirgal, why the loss of a tomahawk would drive him to send smallpox, assessing the role of Baiame and the native-doctors in repelling Tharrawiirgal's malice, and what led to Baiame's anger at the seduction of one of his wives. Second, to what extent can the waganna be viewed as providing evidence of cultural change in postepidemic Wiradjuri society? These problems will be addressed in turn, with additional information on points of detail provided in the footnotes to the Appendix.

In all parts of Aboriginal Australia, there are (or were) large repertoires of mythology that formed the background against which ritual, story, law, and ethics were acted out. ${ }^{115}$ While the Wellington Wiradjuri undoubtedly sang and performed what the missionaries called their "lewd songs" 116 for pleasure and entertainment, they were not pure invention, nor was their purpose solely to "fan the flame of their corrupt desires," as Watson would have it. ${ }^{117}$ On the contrary, it can be assumed that the Baiame waganna enacted a mythic drama that involved existing deities and reinforced their known antagonisms and powers, although it is necessary to rely on later ethnography to tease out what is necessarily a shadowy, partial, and tentative account of the meaning that Wiradjuri men and women attached to their participation in it. Acting on this assumption, the interpretation of the waganna that follows focuses on explanations of the roles played by Baiame, Tharrawiirgal, and the tomahawk whose loss was said to have brought smallpox in the first place.

Baiame was described by later Wiradjuri informants as being the most powerful mythic being in their cosmogony, the source of the magical authority of the bugin, whose various names can be translated as "spirit of the whirlwind," "powerful man," or "clever one." ${ }_{118}$ Baiame's importance is also reported by all early informants on Wiradjuri beliefs. 
Tharrawiirgal, conversely, is not known outside the accounts of the Wellington missionaries. However, Tharrawiirgal does appear to occupy the place allocated in later accounts of Wiradjuri cosmologies and rituals by the one-legged Kamilaroi deity, Daramulun. ${ }^{119}$ In his 1830 account of the Wiradjuri initiation ceremony, Henderson describes another putative adversary of Baiame, whom he calls Mudjegong, the name identified by Howitt from his informant, Murri-Kangaroo, as that of the bullroarer. In other accounts of southeastern cosmologies, the adversary of Eaglehawk was not a human wirinun, however potent, but Crow. ${ }^{120}$ These conflicting fragments of mythological information hint at both the wide variety of religious beliefs among the Aboriginal people of southeast Australia and the possibility that these beliefs were being subjected to strong pressure for change and adjustment.

Taking into account later ethnographic reports, it is possible to make some suggestions as to how the performance elements of the Baiame waganna may have been perceived in Wellington in the I830s. The most careful observations of Wiradjuri rituals relate to the burbung, for which there are extensive descriptions by Mathews and Howitt based on their own observations and the interrogation of native informants in the I890s. ${ }^{121}$ These accounts of the burbung provide a template by means of which the parts played by Baiame, Tharrawiirgal, the wife of Baiame, and Tharrawiirgal's tomahawk might be understood. In twentieth-century ethnographic reports, Daramulun, through his role as the bullroarer voice of Baiame, enforced ritual and cosmological order, including the maintenance of correct marriage relations. According to Berndt and Howitt, the male initiation ceremony included depictions of ground figures of one-legged Daramulun with his attributes of an axe, emu tracks, and emu manifestation as well as dances involving Daramulun and Emu. ${ }^{122}$ The defeat of Daramulun/Eaglehawk by Baiame, the great bugin (Wiradjuri) or wirinun (Kamilaroi), featured as the most dramatic event in the mythic reenactments of the initiation ceremony. The myth or story that underlies this central episode in the ceremony appears to have been lost and the version of the bora ceremony recorded by the amateur folklorist Katie Langloh Parker in Kamilaroi country in the 1890 s is limited to knowledge that might be revealed to a woman. ${ }^{123}$ There may, however, be connections between the myths noted by Parker and those recorded in the lower and upper Murray relating to Crow and Eaglehawk. ${ }^{124}$ Closer to the country of the Wellington Wiradjuri, R. H. Mathews collected myths relating to Eaglehawk, Crow, and the sons of Baiame, which also hint at a relationship of hostile complementarity. ${ }^{125}$ At Wellington, according to Hale, Tharrawiirgal's motivation in bring- 
ing smallpox was that he was "vexed for want of a tomahawk," and the visitation of the smallpox is said to end when Tharrawiirgal's tomahawk is returned. ${ }^{126} \mathrm{~A}$ tomahawk was, of course, an item introduced by Europeans, though we cannot be sure which indigenous object might be referred to by this term. ${ }^{127}$ However, a tomahawk was one of the attributes of Daramulun depicted in sand sculptures and other representations on the bora ground. In Mathews's account of one section of the Wiradjuri burbung, Baiame was said to have hidden in a tree before attacking Emu, not with a tomahawk but with a long spear. ${ }^{128}$ In the sculptural elements of the burbung described by Howitt in the I88os, a molded figure of Daramulun's tomahawk represents the weapon thrown after the Emu as the spirit descends from his sky home. Next to this was a tree with an eaglehawk's nest. ${ }^{129}$ The myths that would explicate these figurative elements of the dance drama do not appear to have survived in full but may be reflected in the myth of the two eagles told by Jimmie Barker ${ }^{130}$ and in earlier published versions. ${ }^{131}$ In this myth the eaglehawk sets up a nest in a tall tree from where it terrorizes the people until the nest is removed by two "clever men" who make themselves invisible and destroy the nests by first using their special tomahawks to chop a hole in the tree to which they then set fire. ${ }^{132}$ Through initiation and a mastery of magic, the clever men sought to emulate the supreme magical authority of Baiame. Tharrawiirgal is thus not to be interpreted as a specific smallpox spirit or as an all-powerful one. Indeed, the clue to the relationship between Tharrawiirgal and Baiame is that Baiame had mastery over him. If Tharrawiirgal was the agent bringing smallpox to Wellington, then Baiame's magical power would surely suffice to overcome him.

Another problem of interpretation concerns identifying the type of cultural transformation for which the Baiame waganna provides evidence. Although it is suggested here that the waganna can be seen as a nativist movement, it is unlikely that the Wiradjuri themselves would have seen the cult as something new. ${ }^{133}$ Overall, it appears similar to the traveling cults noted by a number of observers in both the nineteenth and twentieth centuries. According to Hale, the Baiame waganna was brought to Wellington by "strange natives who went about teaching it." ${ }^{134}$ Hale refers to a traveling cult that had originated with a native "famous for the composition of these songs or hymns," which, according to Lancelot Threlkeld "were passed from tribe to tribe, to a great distance, until many of the words became at last unintelligible to those who sang them." ${ }^{135}$ Howitt also cited a number of other cults, including the Mulunga, though remarkably he seems to have had no inkling of the Mulunga's anti-European features. ${ }^{136}$ Both Watson and Günther appear to have recognized that the 
Baiame waganna was based on the performance of a non-Wiradjuri song, which is consistent with the thesis that they were observing a traveling cult. ${ }^{137}$

With its official messengers, foreign song, large-scale format, and divine inspiration, the Baiame waganna resembles both the Mulunga and the traveling song, accompanied by a carved stick painted red and held by the chief singer, which journeyed down the Murray River and was observed by John Bulmer in Victoria and performed among the Wiimbaio tribe. ${ }^{138}$ In the twentieth century, the clearest parallel to the Baiame waganna is the 'dzi:rguti ceremony described by Berndt, which had a wide distribution throughout Wiradjuri, Wongaibon, Ngiamba, Kominroi, and Maraura tribal territories. ${ }^{139}$ As a child, one of Berndt's informants, Jack King, observed the ceremony in about $\mathrm{I} 872$ at a camp near Conoble Station in Wiradjuri country. According to Berndt, the main purpose of this ceremony was to demonstrate and enforce the authority of the wirinun (native-doctor) over the magic quartz crystals received from Baiame. The ' $k u t i$ (singing) and dance steps of the ceremony were learned by the wirinun while magically consulting the spirits in their camp. The dancing and song were "of the type termed 'dzi:rguti'wskana'jai (of the spirits/dancing/this way)." ${ }_{140}$ Similarly the Baiame ceremony consisted of a 'kuti (Watson's gudthi) or "song" that was performed as part of a 'wakana (Watson's waganna) or "dance."

Finally, it should be noted that the Baiame waganna was not the last song or traveling cult that captured the imagination and enthusiasm of the Wiradjuri. On I8 January I840, while on a visit to a station near Dubbo, about fifty kilometers from Wellington, Günther reported he was "sorry to see" that the young men from the mission who had traveled with him were among the most enthusiastic performers in the wild dance performed that evening. It was "the fresh piece, lately come up" and spreading to all the tribes for hundreds of miles around. Unfortunately, it is at just this interesting juncture that the missionaries abandon their station, and we have no way of knowing what this new dance meant.

\section{Conclusion}

This article has considered the responses of the Wiradjuri people of the Wellington Valley of New South Wales to the smallpox epidemic of I830-I and the demographic and social crisis created in their country by the arrival of Europeans as expressed in the earliest known nativist movement in Australia. The Baiame waganna seems to have had a relatively brief life. From the first mention of the waganna in Watson's journal in October 1833 until 
the final installment of the prophecy in December I835, it lasted for just over two years as an event that impinged on the affairs of the missionaries. Through this brief window of time, the Wellington missionary journals provide a privileged historical view of the formation and transformation of the Baiame traveling cult. As observed by the missionaries, two major changes can be observed in the course of the rise and fall of the waganna. In the first place, the prophecies associated with the Baiame waganna changed in nature from what may have been an initial focus on the aversion of smallpox to an assertion of the need to retain traditional practices, such as the piercing of the septum of the nose, or for women to avoid sexual contact with European men. Second, the waganna appears to have precipitated changes in the local cosmology, including a decline in the acknowledgment of Tharrawiirgal, the spirit thought to be responsible for the coming of the smallpox, and a magnification of the authority of Baiame. Certainly, by the time Murri-Kangaroo was giving an account of southern Wiradjuri myths to Howitt in the I890 and Parker was collecting similar myths from the Eualayi in Kamilaroi country to the north, Tharrawiirgal is regularly replaced by Daramulun.

These changes are unlikely to have been restricted solely to the Wellington area; however, our knowledge of all southeastern people is largely restricted to those groups who were observed by those few Europeans who kept regular records. In the coastal region north of present-day Sydney, it is striking that the agent of the London Missionary Society, Threlkeld, makes no report of All-Father beliefs based on his knowledge of the Awabakalspeaking people who lived north of Sydney in the Lake Macquarie (Awaba) and Newcastle districts. ${ }^{141}$ Howitt argues that the attributes of the Awabakal spirit "Coen" mark him as a parallel to the other southeastern AllFathers and that full knowledge of Coen's stature was hidden because of Threlkeld's status as a noninitiated man. ${ }^{142}$ Despite this ingenious thesis, a more persuasive explanation presents itself, namely, that Coen was not the preeminent figure to the Awabakal, which Baiame apparently was to the Kamilaroi and Wiradjuri. The situation is made more mysterious by a number of parallels between rock carvings in the Sydney area, that is, outside of Wiradjuri and Kamilaroi linguistic regions, which have traditionally been identified with the Wiradjuri and Kamilaroi spirits "Baiame" and "Daramulun" and appear to share some of the attributes attributed to them in the reports of the Wellington missionaries. ${ }^{143}$ All this testifies to the very imperfect nature of our understanding of all Aboriginal religious beliefs in southeastern Australia at the time of European occupation. However, as settlement progressed, it seems very likely that the precise status of the AllFathers and of their significant mythological companions was undergoing 
considerable reassessment both in response to the catastrophe of smallpox and other epidemics, and, in Koepping's phrase, "creative re-adjustment" to the changes wrought by colonization. ${ }^{144}$

We have certainly not exhausted all modes of interpretation of the Baiame waganna. Given the very imperfect survival of cultural information about the Aboriginal people of southeastern Australia, it is to be hoped that deeper understanding will come from a more extensive collaboration between historians with skills in accessing the archival records and ethnographers open to historical evidence of change in Aboriginal society.

\section{Appendix: Glossary of Terms and Chronological Documentation}

\section{Glossary of Wiradjuri, Kamilaroi, and Creole Terms and Names}

The list that follows is a glossary of non-English words and names that appear in this article and in the documents extracted herein. The glossary is keyed to several sources, each of which is documented below.

An orthography for Aboriginal words has yet to be established; however, linguistically respectable texts generally employ what sometimes is called "systematic spelling." Where systematic spelling readings exist for names and terms that appear in this glossary, they are presented in square brackets after the head words and follow Nick Thieberger and William McGregor, eds., Macquarie Aboriginal Words (Sydney, 1994). The head words in this glossary follow A. W. Howitt's models in Native Tribes of South-East Australia (London, 1904; reprint, Canberra, I996), indicated as (H). Howitt's models are usually close to those employed by the missionaries, and they have the advantage of consistency. ${ }^{a}$ Definitions contained in the "Collection of Words and Phrases of the Wirradurrai Dialect," prepared by Rev. James Günther, are indicated by $(G){ }^{b}$ Terms from Günther's journal, cited as (Günther), and from the journal of missionary William Watson, referred to as (Watson), are from the Church Missionary Society Archives (CMS), C N/O 47 and 92, respectively, University of Birmingham Library, Birmingham, U.K. [Australian Joint Copying Project microfilm]. Information provided by the philologist Horatio Hale, indicated by (Hale), comes from his Ethnography and Philology, vol. 6 of United States Exploring Expedition during the years I838, I839, I840, I84I, I842 under the command of Charles Wilkes (Philadelphia, I846). References from the Wesleyan missionary John Harper, indicated by (Harper), are taken from the account he wrote for the Sydney Gazette, published 29 September I825. The source 
referred to as (Henderson) is John Henderson, Observations on the Colonies of New South Wales and Van Diemen's Land (Calcutta, I832).

Babbydal: land of nettles (Watson); location of Baiame waganna.

Baiame [Baayamay]: All-Father (H, 493-4); "Native deity" (G, 228).

Balumbal: angel-like spirits that live on high mountains, eat honey, and do good; note Ballumbambal: "the dead ones, the ancient" ( $G, 162)$.

Bugin: native doctor or clever man (H, 373-4); "a bad spirit" (G, 223).

Burbung [buurbang]: male initiation ceremony ( $\left.\mathrm{H}, 583^{-8}\right)$.

Burrambin: son of Baiame (Hale); "Uncreated, eternal" (G, 248).

Corroborree: dance ritual. Term adopted into creole from Sydney language.

Daramulun [Dharramulan]: Among the Kamilaroi and later the Wiradjuri,

Daramulun was the "boy" or son of Baiame and identified with

Baiame's bullroarer/thunder voice $(\mathrm{H}, 585)$.

Darrawirgal: "a native deity” (G, 253). See Tharrawiirgal.

Gudthi [guudhi, guuji]: song.

Gundyar: deity who gives commands relating to death (Günther). See also Nuyargir.

Koradji: Kamilaroi term for native-doctor (Henderson; H, 384).

Melgong and Yandong: children of Baiame (Henderson).

Moorooberrai [muurruubarraay]: supreme being associated with thunder

(Harper); note Murruburraigarra "to thunder" (G, I63).

Mudjegong: eaglehawk opponent of Baiame (Henderson).c

Mudthir: twigs beaten and burned on Baiame's command during the waganna. From mudthirra, "beating" (Watson).

Murru gian: bone through the nose (Watson).

Nuyargir: conjurers (Hale); "physician" (G, I46).

Tharrawiirgal: "father" of Baiame, lives in the west or northwest (Watson); subsists on fish (Günther); sent smallpox because he was "vexed for want of a tomahawk" (Hale); name derived from tharra [dharrang] "thigh" and wiirgal, "a cutter of wood" (Watson). Has a large tree growing from his thigh (Watson); tree in the form of a rainbow (Günther).

Thunna thunna: "small pox" (G, 254).

Waganna or Waggang nidyal: "dance" (G, I43).

Wandong [wandang]: evil spirit visible only to doctors (Watson); "devil" $(\mathrm{G}, \mathrm{I} 46)$.

Yeener: woman. Term adopted into creole from Sydney language. 
Chronological Dossier of Documents Relating

to Smallpox and the Baiame Waganna

at Wellington Valley, I829-36

I 829

From Charles Sturt, Two Expeditions into the Interior of Southern Australia during the Years I828, I829, I830, and I831, 2 vols. (London, I833; reprint, Adelaide, Australia, 1963):

The most loathesome diseases prevailed among them. Several were disabled by leprosy, or some similar disorder, and two or three had entirely lost their sight. ( $\mathrm{r}: 96$ )

The most loathsome of diseases prevailed throughout the tribes, nor were the youngest infants exempt from them. Indeed, so young were some, whose condition was truly disgusting, that I cannot but suppose they must have been born in a state of disease. ... How these diseases originated it is impossible to say. Certainly not from the colony, since the midland tribes alone were infected. Syphilis raged amongst them with fearful violence; many had lost their noses, and all the glandular parts were considerably affected. (I:I24-5)

I830

Geologist John Henderson visited Wellington in July I830 to report on geological and other scientific matters. His account of native beliefs, Observations on the Colonies of New South Wales and Van Diemen's Land (Calcutta, I832), was part of a scientific project. His informant for the account of "Paime" (the earliest published account) and the Wiradjuri initiation ceremony was Marinbilly, a native-doctor:

Paime is the name of the god of the black people of New South Wales; he is the father of their race, and formerly appears to have sojourned among them. Mudjegong, ${ }^{\mathrm{d}}$ on the other hand, is an evil spirit, who after deriving his existence from Paime, declared war upon him, and now endeavours with all his power to frustrate his undertakings. The offspring of Piame were numerous; but the whole, with the exception of two, were destroyed by Mudjegong, who converted them into different wild animals. A number of the devices on the trees were intended to represent these transmigrations; such as the snakes, the oppossum, the emu, the kangaroo, the cockchaffer etc. ${ }^{e}$ while others were stated to indicate the forked lighting, warlike instruments, and falling meteors. The evil spirit seemed to be described under the form of the eagle-hawk; an imitation of his erie forms a conspicuous object at the upper extremity of the grove.... The two remaining children 
were named Melgong and Yandong; ${ }^{\mathrm{f}}$ who were also the progenitors of the present inhabitants. Piame, having initiated one of these in the mysteries of their religion, having directed him likewise to extract a front tooth from each of the young men, and inculcated the concealment of their sacred rites from women and children, proceeded towards the north; but he is again expected to return at some very distant period. The figure before mentioned represents him in a recumbent position, as he is at present considered to be asleep. There is however a tradition, that he once awoke, and having turned himself upon his side, the flood-gates of the salt ocean were immediately thrown open, and the hills and valleys disappeared beneath the rolling waters. It is also reported, that when he next awakes, a similar catastrophe may be expected. (I47)

I83I

In his chronicle Wanderings in New South Wales (2 vols., London, I834), George Bennett relied on informants, in particular, the surgeon John Mair. Bennett also interviewed George Clark, a convict who lived with the Aborigines during the epidemic:

About two years previous an eruptive febrile disease made its appearance among the natives of Wellington, resembling the small-pox in its principal characters. . . The name that this disease is known by among the aborigines is "Thunna, thunna," or "Túnna, túnna." . . . As far as our information at present extends, it appears not to be an introduced disease. ... At Wellington Valley the same malady was first remarked (as near as could be ascertained) in October last year (I830) and continued to affect the blacks in that vicinity to December. The poor creatures blamed Captain Sturt for its introduction, were much alarmed about it, and are represented as having anticipated some grievous calamity; a great fire and flood were predicted by one of their sages, which would come from Mount Harris and destroy them. From the testimony of George Clark, a convict who had resided with the native tribes, far in the interior, for several years, and was lately taken prisoner by the mounted police, the disease proceeded from the northwest coast, and spared none of the tribes as far as Liverpool Plains, attacking twenty and thirty at a time. ( $1: 148-53)$

Bennett provides description of various forms of treatment by traditional healers, including immersion in water, use of a crystal, even

scorching the hair from the head, and pricking the pustules with a sharp-pointed fish bone, then squeezing out the fluid contained in 
them with the flat part of the instrument. ... The Kradjee (nativedoctor) ... goes through many superstitious ceremonies to cure his patients. The Lachlan and Wellington Valley tribes call it Thunna, thunna. (I:I54)

Bennett makes use of the report of Mair, who

also says that he heard a most lugubrious dirge chaunted at a Corobera at Bathurst, commemorative of this destructive epidemic, and judged accurately of its nature from the melancholy and solemn nature of the pageant. (I:I55)

The remaining extracts are taken from the journals of the three missionaries at Wellington Valley: Johann C. S. Handt, William Watson, and James Günther (all from the Church Missionary Society Archives [CMs], C N/O 47, 5I, 70, and 92, University of Birmingham Library, Birmingham [Australian Joint Copying Project microfilm]). Handt and Watson arrived at Wellington on 3 October I 832 . Günther arrived at the mission on 8 August I837, whereupon he replaced Handt, who had left with his wife for Moreton Bay in 1836 . In addition to journal entries for the CMS, the senior missionaries also completed annual reports for the government. This accounts for some chronological overlap in the entries.

I832

Handt Journal, 5 December: Besides the small pox, which made great havoc among the Blacks two years ago, influenza is said to be again raging among them lower down the country.

Handt Journal, I3 December: A little interesting girl was encountered on a stock-station. . . . Her father and mother died of the small pox two years ago in the bush, where she covered the corpses, as well as she could with grass and earth. ... [S] he has been living with the hut keeper ever since.

I833

Watson Journal, 27 August: Gentleman Jackey came this morning with other natives to cut bark. I had a long conversation with him but he is as hard as the nether millstone. He says he has four yeeners and so is a gentleman. He has indeed 4 yeeners who are all "farmed out" as it were to white men by whom he is well supplied with food \&c. Horrid work indeed!!! The natives repeatedly say that if they will not lend yeeners white fellow take them by force. 
Handt Journal, 30 September: A few blacks, who have been frequently here before returned to day from the place where they had been to coro-bera.

Watson Journal, 4-5 October: They are to have a corrobora this evening respecting thannah thannah (the small pox). They say it will never come here again. ... Three of the natives returned from the corrobora last night about II O'clock and several more today. It appears that on their way last evening one of our boys reproved a native for swearing and was severely beaten by the aggressor for this act of X'n kindness, for so I think I may term it.

I834

Watson Journal, 22 April: The Natives here have got an idea that the world is shortly to be partially destroy'd by a flood. That they will live in a large hut which they intend to build, but before the inundation animals of every kind will of their own accord go into the hut. They have learnt this from some one celebrated Native who lives near to a large river. I asked them many questions on the subject, but it is enough for them that they have been told that it will be. They use no arguments and they appear to be exceedingly angry if the truth of what they relate is disputed.

HANDT Journal, I May: Some Blacks who came to day, said that the dance should take place to-night a few miles from here with others of their associates and they soon left for that purpose.

Watson Journal, I May: This evening several natives came up on their way to a corrobbara at a neighbouring station. Our young men wished also to go. I used my utmost endeavour to dissuade them from going, but without effect. Goongeen said they would return early tomorrow morning.

Watson Journal, 2 May: They had not a corrobbara last evening on account of the rain. They will have one tonight.

Watson Journal, I7 May: Goongeen is now suffering from the effects of going to the late Corrobbara. He there caught the disease. This is the first time I have known him to have been afflicted with it. Though he has been so much here and has received so much religious instruction he has not yet seen the impropriety of adulterous intercourse. Though it is a law among them that the young men shall not come near to the place where espoused females are, at their corrob- 
baras the married men almost compel the young men to commit adultery. ${ }^{\mathrm{g}}$

Handt Journal, 5 and 8 September: The Blacks were nearly all painted this morning. . . . The young men sang at night with great animation and cheerfulness some of their heathenish songs.

Handt Journal, 22 December: Most of the Blacks left here today to go to Cobolyen, where there was to be a dance, as I was informed.

Handt Journal, 29 December: Went around to all the Blacks in the Camp, and talked to them. On counting them, I found that they were ninety-six in number . . one of the largest parties that have been at Wellington. There were several strange Blacks among them.

Handt Journal, 23 March: The disease which raged in Sydney a few months ago, called the influenza, has also made its appearance in these parts.

Watson to [Reverend Richard] Hill [SECRetary of the Sydney Corresponding CommitTeE OF THE CMS], 25 March: We have only a few natives here this quarter. They are now taking their females and children from every station to assemble at a general Corobbera to Byamy their maker. What is the meaning of this? I hope to be there. They say white man stole Byamy's wife and he is going to kill all white man, and all the natives that are found with them. (CMs, CN/o5 [a])

Watson Journal, 28 March: The Natives have received information that Byamy will kill all the girls and women who live with white men, so that there is not a female native to be found at any station for many miles around. Moreover the Natives have a large meeting at a place called Bahbyjal to hold a feast or have a corrobbora to Byamy, and all the natives who are not present will be killed. Several months ago we had a report prevalent among the natives, that Byamy had been insulted in some way by some white men, and that he was going to kill all white persons everywhere. Our Natives here planned among themselves how they would act when that event took place. They would dress us in new Clothes put us in boxes and bury us. Gungin would put the window blinds down, and pack up all the articles to take into the Bush. Mr Handt's boys were to do the same with Mr and Mrs Handt and their clothes etc. I supposed that report had died away as I have not now for some time heard anything of it but something relative to it is revived in the present proceedings. The Song to be chanted at the 
Corrobarra is made by Byamy, has been sent by a Lizard from who it was communicated to some Natives. There are certainly circumstances here that involve some interest.

Watson Journal, 6 April: Intelligence has reached us that Gentleman Jackey is dead. This is a circumstance that may affect the minds of some of the Natives. They have been collected from a distance of many miles in every direction to celebrate Waganna "a dance" to Baiami a being of considerable note among them. The place at which they assembled is Babidyal; literally the land of Nettles, from Bábin "a nettle." It was said a short time ago that Baiami was about to kill all the Europeans in this country because some of them had seduced his wife. That prophecy passed away without being fulfilled; now it is reported that he will destroy all the Natives who either live with Europeans; lend their females or children to them; or, do not celebrate this Waganna. Gentleman Jackey had six wives, if that honourable name be allowable here, of whom not more than one was generally with him. The others were living with Europeans, from whom he received the wages of iniquity. Jackey had united with his brethren in the Waganna; but that same night was taken with, according to the representations of the natives, violent pain at the heart and died two days afterwards. He was probably not more than 35 years of age; and was more free from disease than any other I have known of his age. Baiami is said to live in the East, and Tharrawiirgal, his father, in the West. Both live near the Sea. ${ }^{\text {h }}$ The Natives say that when Baiami gave the Gudthi "song" which they now chaunt to him, he gave them also wooden gods which after the first celebration of the Waganna they burnt. He also commanded them to use small Twigs about 9 inches in length which they were to beat against each other in the Waganna and then to burn them. These Twigs are named Mudthir from Mudthirra which signifies repeated beating or, thrashing. It is said that the road taken by Baiami and his wife ${ }^{i}$ when they left the house of Tharrawiirgal is marked by deep pits in the earth where they slept. ${ }^{j}$ In one place is a small mountain of stone of a superior quality; ${ }^{\mathrm{k}}$ One night when Baiami was on his way, he was bitten by an ant, ${ }^{1}$ and from the wound immediately proceeded this mountain. The natives say Baiami is not to be lightly spoken of, nor his song taken in vain. His father Tharrawiirgal is said to be the author of Thanna thanna (small pock). He has his name from a large tree growing out of his thigh; Tharrar "thigh," and wiirgal "a cutter of wood." Burrambin "the uncreated one" is said to be the greatest of all beings; But the Natives say little about him. ${ }^{\mathrm{m}}$ The circumstance of their having apprehensions of such superior beings is more 
than was at first anticipated They have a name for angels which they say live on a high mountain, whose food is only honey, and whose employment is like Parson's. They are said to be white. I have now no doubt that there is among these native a settled belief in the existence of a "First cause."

Handt Journal, 23 April: The natives had a dance this evening. As they appeared to be highly gratified with this amusement, and were anxious for us to be there, we went to witness it. On approaching the spot, we saw a number of young men jumping and dancing before a fire, sometimes bending down towards the fire, shaking their limbs and heads, ${ }^{n}$ and all the while screaming. ... A number of women stood in a group at one side, and sang ... their parts of the song."

Watson Journal, 24 April: They have had a "Waganna" or Native dance tonight in which they sang to Baiami. When they were ready they sent messages with fire sticks to summon us and direct our path. They beat small sticks as mentioned above. The song is very short, and all that I could learn from it or of it was something respecting angels; carrying on the back; playing to him; and throwing into the fire. Their Poets enjoy like all others the liberty of using language different from what is used in general conversation.

Watson Journal, 8 May: Seventy natives here, they have had a Waganna to night. In general their songs are of the lowest and most obscene description; calculated only to fan the flame of their corrupt desires. As are their songs, such are their practices. It is impossible for any human beings to be guilty of vices more abominable.

WaTsOn Journal, I7 October: They have some more superstitious prophecies afloat among them. They say that shortly there will be a general flood and all the mountains will fall down because Neddy has died [a native noticed in the last quarter Journal].

Watson Journal, 8 December: Kabon Bartharai has come up to warn the natives that another Messenger will soon arrive to summon them to sing to Baiame, who it is said has given them another (annual) revelation to which they (in general) consider themselves bound to attend. They all old and young-male and female must appear at the anticipated Waggang nidyal or "native dance" with Murru gian "a bone through the cartilage of the nose" ${ }^{\mathrm{P}}$ or Bai[a]mi will inflict the punishment of death on the delinquent.

Watson Journal, i6 December: A large number of natives came up to day. They are assembling from all quarters to be ready for the new 
revelation. O when shall they assemble from all quarters anxious to hear of the Revelation of mercy and grace through our Lord Jesus Christ! In a moment-in the twinkling of an eye Almighty grace can constrain them. Without it all efforts are and must for ever be abortive.

Watson Journal, i9 December: Our girls are evidently uneasy at what the natives say will be the consequence of their not having bones through their noses, and not associating with them in their Wagganna. Hence we frequently detect their feeling at the cartilage of the nose or probably endeavouring to make a hole through it with the nails of their finger and thumb.

Watson Journal, 22 December: About 70 natives here at present. To day we gave them a Bullock weighing 500 pounds to themselves, and this evening some of them came up and said that they had not got any. A report has reached them that the soldiers are going to do something with the men, and to take all the females and give them to Europeans. I argued with them for an hour on the falsity of the Report; but could not persuade them to believe it was not true. I referred them to many such reports which had been spread and which at the time I told them were false, and they had proved to be so.

Watson Journal, 29 December: The natives say that Tharrawirgal (one of their Divinities who lives in the N.W. and who is said to be the author of the Small Pox) is not angry with them now that he will never send the Small Pox again because he has now got a Tomahawk which he formerly wanted. I was sorry to hear that a native youth, who has lately taken a wife, allowed her to sleep at a house on this Establishment during the whole of Sunday night. I spoke to him this morning on the subject, he denied it, so far it appeared that he was either ashamed or afraid of its being known by me. He charged me with taking females from natives and keeping them altogether. I told him that one of the girls was thrown away by her husband, and had long been living with a European before she was given to us, and that the other was given by her mother to us. Kabbarrin accosted me with. . . . : "What do you want with Black yinars (wives or females). Why don't you go to Sydney? plenty white yinars sit down there. Yes yes you get plenty of children by and by.

I 836

Watson RePORT FOR I836: It has been found extremely difficult to form an accurate idea of the opinions of the natives in reference to the Creation of the world, the Creator, the immortality of the Soul and a 
future state of existence; as the accounts given by different natives are frequently at variance with each other. It appears however that there is among them a general idea of a Creator who, himself, is uncreated. (Some say that Baiamai is the uncreated one and that Burrambin is his Son; that Baiamai spoke and his son sprang up at once. Others say that Burrambin is the father, and Baiamai the Son.) They believe in the immortality of the Soul; but what is its state of employment after death has not been learnt. They have an idea of an order of beings inferior to the Creator but Superior to man. These it is said are white, live on a high mountain, eat only honey, and their employment is singing. They attribute all their afflictions and troubles to "Wandong," an evil being which is said to be visible only to the doctors. ${ }^{9}$ Though they attribute all their evils to Wandong as the author, they often ascribe them to other natives as the instruments, who they say, have power to afflict, and even to kill at a distance of hundreds of miles when so disposed. The only kind of worship known among them is the "Wagganna" or native dance accompanied by singing to Baiamai who annually, about February or March, reveals to some one native, at a very great distance from Wellington, "the Song" in which all are bound to join under penalty of death. This Song is esteemed Sacred by the Natives who apprehend that if they should not be present at the Singing of it they would die.

I 838

Watson's account of the Baiame Waganna is the likely source for the account of the religious beliefs of the Wellington Aborigines published by linguist Horatio Hale in Ethnography and Philology (vol. 6 of United States Exploring Expedition during the years I838, I839, I840, I84I, I842 under the command of Charles Wilkes [Philadelphia, I846]). Hale visited Wellington in $\mathrm{I} 840$ with the expedition.

The lack of religious feeling in these natives has already been mentioned. The missionaries have found it impossible, after many years' labor to make the slightest impression upon them. They do not ascribe this to any attachment, on the part of the blacks, to their own creed, if such it may be called, for they appear to care little about it. Some of their ceremonies, which partook of a religious character, have been lately discontinued, but nothing has been substituted in their place. It is not true, however, as has been frequently asserted, that the natives have no idea of a supreme being, although they do not allow this idea to influence their actions. The Wellington tribe, at least, believe in the existence of a deity called Baiamai, who lives on an island beyond the 
great sea to the east. His food is fish, which come up to him from the water when he calls them. Some of the natives consider him the maker of all things, while others attribute the creation of the world to his son Burambin. They say of him, that Baiamai spoke, and Burambin came into existence. When the missionaries first came to Wellington, the natives used to assemble once a year, in the month of February, to dance and sing a song in honor of Baiamai. This song was brought there from a distance by strange natives, who went about teaching it. Those who refused to join in the ceremony were supposed to incur the displeasure of the god. For the last three years the custom has been discontinued. In the tribe on Hunter's River, there was a native famous for the composition of these songs or hymns, which, according to $\mathrm{Mr}$ Threlkeld were passed from tribe to tribe, to a great distance, until many of the words became at last unintelligible to those who sang them.

Dararwirgal, a brother of Baiamai, lives in the far west. It was he who lately sent the small-pox among the natives, for no better reason than that he was vexed for want of a tomahawk. But now he is supposed to have obtained one, and the disease will come no more. The Bálumbal are a sort of angels, who are said to be of a white color, and to live on a mountain at a great distance to the southeast. Their food is honey, and their employment to do good "like missionaries."

It is possible that some of these stories owe their origin to intercourse with the whites, though the great unwillingness which the natives always evince to adopt any customs or opinions from them militates against such a supposition. But a being who is, beyond question, entirely the creation of Australian imagination, is one who is called in the Wellington dialect Wandong though the natives have learned from the whites to apply to him the name of devil.... If they are ill, they say Wandong has bitten them. No one can see this being but the núyargir, or conjurors, who assert that they can kill him, but that he always returns to life. He may, however, be frightened away by throwing fire at him. ${ }^{\mathrm{r}}$ (IIO-II)

I839

GÜNTHER JOURNAL, 4 January: In endeavouring to elicit a number of words from one of the Native youths, I was led to make various enquiries about their fictitious deities. All I could learn of Baiamai, the principal god, is that he lives in the East, subsists on bread, he has birds' feet resembling those of an emu, ${ }^{\mathrm{s}}$ he has two wives. ${ }^{\mathrm{t}}$ Natives who 
live far off, towards the East, sometimes saw him. He lives for ever. Darrawirgal, another deity, lives in the West, subsists on fish. He sent the small pox by which so many Natives were snatched away a few years since. A tree in the form of a rainbow is growing out of one of his thighs."

GÜNTHER JOURNAL, I2 January: In the evening I had a long talk with Fred respecting various superstitious notions entertained by the Aborigines. He appeared to be better versed in them than most. That these superstitions are more deeply rooted in them than is generally believed, I am more and more convinced. I was informed of another deity called Gundyar, ${ }^{\mathrm{v}}$ who is supposed to live in heaven. His principal office is to give commands as it regards the death of a person. It is also supposed that he had a hand in the creation of the world, though creative power is principally ascribed to Baiamai. I was told of a demon that frequently takes possession of Natives \& makes them ill.

I 840

Günther reported on this ceremony from Dundullimal, a station belonging to the Lawson family on the Macquarie River near Dubbo, about Ioo kilometers from Wellington.

GÜNTHER JOURNAL, I8 January: After dark the Blacks commenced a great dance, at which I was present; and a number of Europeans. I was sorry to see our Young men were among the principal performers. It was the wildest and most curious dance I ever saw-the fresh piece; lately come up, \& now going to all the tribes for, perhaps hundreds of miles. They were all down the front painted quite white, except just in the middle beginning from the forehead one black streak was left. The number of Natives present was about a hundred.

\section{Circa 1860}

Twenty years after leaving Wellington, James Günther recorded a few more details of a ceremony to Baiame based on reports to him by some young men of the mission ("Lectures on Aboriginal People of Australia," Sydney, Mitchell Library, MS Z B505). Although Günther claims to have remembered this occasion, he did not arrive at the mission until I835, and he made no record of another ceremony involving months of preparation in his contemporary journals.

I will give you the description the Blacks gave me of Baiamai in their own simple way of expressing themselves. Baiamai is altogether good and always likes to do good. He always has been and always will be 
or more literally he always long ago did sit down and always will sit down. What ever he wants to be done will be done, he only needs say a command and it will come; if, for instance he wants to eat fish, he only needs say the word $\&$ fish will come to him out of the water. Here you will observe we have at once the attributes of eternity, of goodness, of omnipotence. He is also said to have a son, called: [Blank in manuscript] Either himself or his son sometimes send a message mostly accompanied by a song which it appears is sung in honor of him or at his command. I remember on one occasion, there was a great gathering of Blacks in the district of Wellington, many distant tribes assembled it took some months, from the first announcement of it, till all that were expected had arrived. There were some present who spoke different dialects. There was only one of the young Aborigines who was always much attentive and candid to me who ventured to give me a few particulars of the ceremony, but enjoined me never to betray his communication to others. His statement asserted that there was a particular spot fixed upon them and certain mysterious figures cut on bark were produced, fixed in place more or less surrounded by a sort of rough enclosure to resemble a chamber. To this place they went in solemn procession and made certain obeisances, and other mysterious movements, sang a song sent by Baiamai and finished with a sort of dance. The song of which a portion was related to me was unfortunately not in the Wurudurei dialect only a few odd words resembling it, so that neither I nor the young man could make meaning of it. (I09I6)

\section{Notes to Appendix}

a For a clear exposition of Howitt's principles, see his "Directions for Spelling the Native Words," included in Howitt and Alfred Fiston's survey questionnaire of I874, reproduced in Mary Howitt Walker, Come Wind, Come Weather (Melbourne, I97I), 327.

b Sydney, Mitchell Library, MS B503, pp. I39-347. A version of this appears in J. Fraser, ed., An Australian Language (Sydney, I982), Appendix, 56-I2O. For other Wiradjuri vocabularies see Lancelot E. Threlkeld, "Grammar and Vocabulary of . . . Wirradhuri," in E. M. Curr, The Australian Race, 3 vols. (Melbourne, I886-7), 3:363-40I; R. H. Mathews, "The Wiradyuri and Other Languages of New South Wales," Journal of the Anthropological Institute (U.K.) 34 (1904): 284-305.

c All other lists have mallion or mullian for eaglehawk. See note $\mathrm{d}$ for mudjigang meaning the bullroarer.

d According to A. W. Howitt, in the Wiradjuri burbung, Mudjigang or Bobu was the name of the sacred bullroarer, sometimes said to be the voice of Baiame. 
Howitt, The Native Tribes of South-East Australia (London, I904; reprint, Canberra, I996), 583. The bullroarer was used as an emblem of the messenger charged with summoning participants to the ceremony and was also a threat to enforce ritual order. Howitt also notes that another name of the bullroarer was Daramulun. Ibid., 456.

e According to K. Langloh Parker, the bora ground included representations of the "camps" of numerous totemic groups. Parker, comp., and Henrietta Drake-Brockman, ed., Australian Legendary Tales (London, I896), I5.

$\mathrm{f}$ The boys of Baiame feature in the story that forms the mythic substratum of the male initiation ritual. Ibid. They are also represented as guardians of the Kamilaroi bora ground, where one was decorated with emu feathers and the other carried a shield. Janet Mathews, The Opal That Turned into Fire, ed. Isobel White (Broome, Australia, 1994), 93. Mathews notes their Kamilaroi names as Bobarilbah and Byalbura.

g Ronald M. Berndt and Catherine M. Berndt note that an exchange of wives for coitus was one of the concluding rites of the initiation ceremonies in southeast Australia. Berndt and Berndt, A World That Was: The Yaraldi of the Murray River and Lakes, South Australia (Melbourne, I993), 28. Wife exchange also featured as part of ceremonies in which Wiradjuri clever men demonstrated their powers. R. M. Berndt, "Wuradjeri Magic and 'Clever Men,'” Oceania I8 $($ I946-7): 340 .

h In contrast, Berndt notes that Baiame came "from the other side of the sea," which Berndt interprets as being toward the west. Berndt, "Wuradjeri Magic," 334 n. I6.

i According to Berndt, the wife of Baiame was a spirit creature known as a Kurikuta. Ibid., 77.

j The paths taken by mythic heroes were often represented by patterned furrows on the ceremonial ground. Berndt reproduces Ronald Kerry's photographs of the Bora ceremonies, which include many examples. See R. M. Berndt, Australian Aboriginal Religion (Leiden, 1974), figs. 42-56.

$\mathrm{k}$ According to Mathews (as cited by Berndt), the crystal home of Baiame was known to the Kamilaroi as Kurrilwan. See Berndt, "Wuradjeri Magic," 334 n. I6.

1 During the training of a Wiradjuri clever man, Baiame provided magical instructions that the trainee was not to sit directly on the ground but to protect himself with leaves. This was in case the clever man was bitten and killed by ants whose poisonous sting, made of liquefied quartz crystals, had been put into them by Baiame. See Berndt, "Wuradjeri Magic," 338; Berndt, Australian Aboriginal Religion, 28.

$\mathrm{m}$ A possible parallel with this (otherwise unattested) figure is the Biamban ("Master"), who appears to function as a ceremonial leader among the Yuin and other southeastern tribes. Howitt, Native Tribes, 3I4. Baiame was the Biamban over everything. Berndt noted that his informants did not support this attribution. Berndt, "Wuradjeri Magic," 340.

$\mathrm{n}$ Berndt describes demonstrations of control over fire by clever men particularly during initiation ceremonies. Ibid., 73-75, 34I-2.

o Women were present as both actors and audience at all significant ritual events, including male initiation.

p Howitt describes the perforation of the septum as a custom performed on chil- 
dren prior to initiation. Boys were treated by old men and girls by old women. Howitt, Native Tribes, 740-I.

$\mathrm{q}$ Wondung is the name given to sacred dances performed during the Wiradjuri burbung. Ibid., 586 .

r Günther's word list glosses Ballumbanbal, "the dead ones, the ancient," and Nguiargir, "physician." Günther, "Collection of Words and Phrases of the Wirradurrai Dialect,” Sydney, Mitchell Library, MS B503, pp. I46 and I62. For spirit beings other than sky gods, see Howitt, Native Tribes, 475-88; for southeastern beliefs in the soul (warangun) and ghosts (djir), see Berndt, Australian Aboriginal Religion, 26-30; Howitt, Native Tribes, 439-40.

$\mathrm{s}$ Emu meat was sacred to Baiame and forbidden to all youths prior to their initiation. Berndt notes that Emu was the assistant totem of Baiame's wife, who was a Kurikuta, or ancestral being. Berndt, "Wuradjeri Magic," 77. The male initiation ceremony included depictions of ground figures of Daramulun with his axe, emu tracks and emu manifestation as well as dances involving Daramulun and Emu that depicted their mythological relationship. See Berndt, Australian Aboriginal Religion, 27-28.

$\mathrm{t}$ Wives play important roles in mythic accounts of the creative journeys of AllFathers in Kamilaroi and Yaraldi. Parker, Australian Legendary Tales, I2-24, on the creation of Narran Lake; Berndt and Berndt, A World That Was, 223-7.

u Daramulun was depicted with an elongated penis around which dances were performed. Berndt, Australian Aboriginal Religion, 29. However, there are rock engravings from coastal regions near Sydney that depict human figures with feathered headdresses and objects that look like clubs or bullroarers protruding from their bodies. One holds a curved object that may be a "tomahawk." Peter Stanbury and John Clegg, A Field Guide to Aboriginal Rock Engravings (Oxford, I990), 87, fig. 88. The major carving site at Devil's Rock, Maroota, depicts both the human Daramulun with his rainbow penis and his emu manifestation (or wife?) with his one club foot, bearing an object that could be either a shield or bullroarer. Ibid., 98-99, figs. 62-63; F. D. McCarthy, "Rock Engravings of the Sydney-Hawkesbury District," Records of the Australian Museum 24 (I959): 2II-3, fig. 6.

v Perhaps the same as Hale's nuyargir, which also appears in Günther's word list as nguiargir (physician).

\section{Notes}

An early version of this article was presented to the Contagion Conference, University of Sydney, 7-8 April 1999. Hilary M. Carey thanks the Humanities Research Centre of the Australian National University for facilities that enabled her to complete the rewriting of this article in January and June $200 \mathrm{I}$.

I In 1996, there was wide reporting of the decision to destroy stocks of the virus, e.g., "wHo Sets Date to Destroy Smallpox Stocks," Public Health Reports III (September-October I996): 388. However, at the time of writing, in June 200I, this has not yet happened. In I999, a WHO press release reported that the wHO Advisory Committee on Variola Virus Research recommended retaining the world's two remaining smallpox virus collections for scientific purposes, including DNA sequencing, until as late as 2002. See "Future Research on 
Smallpox Virus Recommended," wHO press release, Io December I999. Available on-line at www.who.int/inf-pr-I999/en/pr99-77.html (accessed 22 January 200I).

2 For a recent review of demographic arguments, see Linea Sundstrom, "Smallpox Used Them Up: References to Epidemic Disease in Northern Plains Winter Counts, I7I4-I920," Ethnohistory 44 (I997): 305-43. For the difficulty in assessing precontact evidence of smallpox impacts, see Robert Boyd, "Commentary on Early Contact-Era Smallpox in the Pacific Northwest," Ethnohistory 43 (1996): 307-28. The debate about the virulence and long-term impact of epidemic disease on Aboriginal populations in the New World has even reached the popular scientific press. See Heather Pringle, "The Plague That Never Was," New Scientist, 20 July 1996, 32-35.

3 The major studies of the impact of smallpox on Aboriginal populations in the early settlement period are those by Judy Campbell and Noel G. Butlin: Campbell, Invisible Invaders: Smallpox and Other Diseases in Aboriginal Australia, I780-I880 (Melbourne, 2002); Campbell, "Smallpox in Aboriginal Australia, I829-3I," Historical Studies 20 (I983): 536-56; Campbell, "Smallpox in Aboriginal Australia, the Early I830s," Historical Studies 2I (I985): 337-58; Butlin, Our Original Aggression: Aboriginal Populations of Southeastern Australia, I788-I850 (Sydney, I983); and Butlin, "Macassans and Aboriginal Smallpox: The 'I789' and 'I829' Epidemics," Historical Studies 2I (I985): 31535. In a more recent contribution, Alan Frost provides a thorough rebuttal of Butlin's suggestion that the I 789 epidemic was deliberately introduced: Frost, Botany Bay Mirages: Illusions of Australia's Convict Beginnings (Melbourne, I994), I90-2IO. Studies of the impact of epidemic disease elsewhere has been more sporadic, but for central Australia, see R. G. Kimber, "Smallpox in Central Australia: Evidence for Epidemics and Postulations about the Impact," Australian Archaeology, no. 27 (I988): 63-68.

4 J. Burton Cleland, "The Naturalist in Medicine with Particular Reference to Australia," Medical Journal of Australia I, no. I7 (April I950): 553-62. For the "Macassans," see C. C. Macknight, The Voyage to Marege: Macassan Trepangers in Northern Australia (Melbourne, I976).

5 See, for example, Eric Rolls, Sojourners (Brisbane, I993), 300.

6 For the debate about Butlin's thesis, see Charles Wilson, "History, Hypothesis and Fiction: Smallpox and Aboriginal Genocide," Quadrant 29 (March I985): 26-32; Noel Butlin, "Reply to Charles Wilson and Hugh Morgan: Aboriginal Depopulation," Quadrant 29 (June I985): 30-33; Charles Wilson, “Aboriginal Depopulation: A Rejoinder to Noel Butlin," Quadrant 29 (July I985): I7-I9. See also Alan Gray, "Some Myths in the Demography of Aboriginal Australians," Journal of the Australian Population Association 2 (November I985): I3649. Butlin also downplays the significance of the smallpox epidemics on the Aboriginal subsistence economy in his more recent Economics and the Dreamtime: A Hypothetical History (Melbourne, 1993).

7 R. H. W. Reece, Aborigines and Colonists: Aborigines and Colonial Society in New South Wales in the I830s and I840s (Sydney, I974), 28-52.

8 For a study of the ghost dance as a religious response to demographic crisis, see Elizabeth Vibert, “'The Natives Were Strong to Live': Reinterpreting Early Nineteenth-Century Prophetic Movements in the Columbia Plateau," Ethnohistory 42 (1995): 197-229. 
9 Anthony D. Buckley, "God of Smallpox: Aspects of Yoruba Religious Knowledge," Africa 55, no. 2 (I985): I87-200; for aspects of the Hindu goddess who rules over smallpox and other infectious diseases, see Ralph W. Nicholas, "The Goddess Sitala and Epidemic Smallpox in Bengal," Journal of Asian Studies 4I (I98I): 2I-44; Margaret Trawick Egnor, "Changed Mother or What the Smallpox Goddess Did When There Was No More Smallpox," in South Asian Systems of Healing, ed. E. Valentine Daniel and Judy F. Pugh (Leiden, I984), 24-45; Geoffrey Samuel, "Women, Goddesses, and Auspiciousness in South Asia," Journal of Interdisciplinary Gender Studies 2, no. 2 (I997): I-23 and references cited in note $\mathrm{I} 3$ of that work.

Io Report of the Aboriginal Mission I836 compiled from the Reports of Messrs Watson and Handt, Church Missionary Society Archives, Foreign Division, Overseas Missions series, C N O 92/29, University of Birmingham Library, Birmingham (hereafter CMS).

II For a careful review of the terminology for new religious movements in preindustrial and colonized societies, including nativist, neotraditionalist, revitalist, messianic, prophet, cargo, and millenarian movements or cults, see Garry Trompf, "Millenarism: History, Sociology, and Cross-Cultural Analysis," Journal of Religious History 28, no. I (2000): I03-24. For Native American religions, the debate is summarized in Russell Thornton, We Shall Live Again: The I870 and 1890 Ghost Dance Movements and Demographic Revitalization (Cambridge, U.K., I986), chap. I.

I2 Most studies of Aboriginal "nativist" movements in Australia are restricted to the late nineteenth and the twentieth centuries and to the northern and western frontiers. For an overview, see Erich Kolig, "Religious Movements," in The Australian People: An Encyclopedia of the Nation, Its People, and Their Origins, ed. James Jupp (Sydney, I988), I65-7; Erich Kolig, "Post-Contact Religious Movements in Australian Aboriginal Society," Anthropos 82 (I987): 25I-9; Klaus-Peter Koepping, "Nativistic Movements in Aboriginal Australia: Creative Adjustment, Protest, or Regeneration of Tradition," in Aboriginal Australians and Christian Missions: Ethnographic and Historical Studies, ed. Tony Swain and Deborah Bird Rose (Adelaide, Australia, I988), 397-4II.

I3 For summary, see Les Hiatt, Arguments about Aborigines (Cambridge, U.K., I995), I00-II9; for the later fate of Baiame, see Hilary Carey, "The Land of Byamee': K. Langloh Parker, David Unaipon, and Popular Aboriginality in the Assimilation Era," Journal of Religious History 22 (I998): 200-I8.

I4 Tony Swain, A Place for Strangers (Cambridge, U.K., I993).

I5 For reviews of Swain, see Australian Journal of Anthropology 4, no. 2 (I993): 96-IIo; Oceania 65, no. I (I994): 94-95; Anthropos I-3 (I994): 3I2-3.

I6 Swain, A Place for Strangers, I45, notes that the first evidence of the "cult of Baiami" comes from Wellington among the "heavily missionised" Wiradjuri. In fact, the earliest account of Baiame is Henderson's, which is based on observations made during his I 830 visit. There was a brief, ineffective mission conducted by the Wesleyan John Harper, but his information is very unreliable. In an account of the mission published in the Sydney Gazette, 29 September I825, Harper claimed there was a Supreme Being who the Wellington blacks called "Moorrooberrai" and who was believed to produce the thunder and lightning. According to James Günther's Wiradjuri word list, Mitchell Library MS B503, p. I63, murruburraigarra means "to thunder." 
I7 Helmut Petri, Gisela Petri-Odermann, and Erich Kolig, trans., "A Nativistic and Millenarian Movement in North West Australia," in Aboriginal Australians and Christian Missions, 39I-5, refers to "nativistic and millenarian movements" as "largely, but not total[ly] absent from Australia."

I8 For example, in his article on "revitalization movements," Anthony F. C. Wallace asserts that Australia (and Tasmania) was the only major cultural area in which such movements were completely unknown. David L. Sills, ed., International Encyclopedia of the Social Sciences (London, I968), II:7.

I9 Kolig, "Religious Movements," I65.

20 Koepping, "Nativistic Movements," esp. 396-7.

2I Ibid., esp. 398. For the potential importance of missionary records for accounts of traditional religion, see J. D. Y. Peel, "Problems and Opportunities in an Anthropologist's Use of the Missionary Archives," in Missionary Encounters: Sources and Issues, ed. Robert A. Bickers and Rosemary Seton (Richmond, U.K., I996), 70-94.

22 The settlement merited a visit from Augustus Earle, the official artist onboard Darwin's Beagle in I826. Earle made a sketch of the convict establishment from the vantage point of the commandant's house, placing a Wiradjuri warrior in the foreground. The watercolor, now in the Rex Nan Kivell Collection [NKI2/24], National Library of Australia, can be viewed from the library's online image collection, Image I, available at www.nla.gov.au/cgi-bin/imagesI/ pic? $13404+\mathrm{d}$. Note also the front and back portraits of the same warrior displaying his cicatrices, drawn at the same time, at www.nla.gov.au/cgi-bin/ imagesI/pic? I34I3 $+\mathrm{d}$ and www.nla.gov.au/cgi-bin/imagesI/pic?I34I2 +d.

23 David A. Roberts, "A Sort of Inland Norfolk Island? Isolation, Coercion, and Resistance on the Wellington Convict Station, I823-26," Journal of Australian Colonial History 2 (2000): 50-72.

24 Ralph Darling to George Murray, 4 May s830, Historical Records of Australia, ser. I, vol. I4, p. 465.

25 N. B. Tindale, Aboriginal Tribes of Australia: Their Terrain, Environmental Controls, Distribution, Limits, and Proper Names (Canberra, I974).

26 Peter Read, " “A Rape of the Soul So Profound': Some Reflections on the Dispersal Policy in NSW," Aboriginal History 7 (1963): 23-32; Read, "Breaking up These Camps Entirely," Aboriginal History 8 (1984): 45-55; Read, A Hundred Years War: The Wiradjuri People and the State (Canberra, I988).

27 Henry Reynolds, The Other Side of the Frontier (Ringwood, Australia, I982). On the early contact history around Bathurst and Wellington Valley see T. Salisbury and P. J. Gresser, Windradyne of the Wiradjuri: Martial Law at Bathurst in I824 (Sydney, I97I). Pivotal works from this period include Charles D. Rowley, The Destruction of Aboriginal Society (Canberra, 1970); Raymond Evans, Kay Saunders, and Kathryn Cronin, Exclusion, Exploitation, and Extermination: Race Relations in Colonial Queensland (Sydney, I975) (and the later edition, Race Relations in Colonial Queensland: A History of Exclusion, Exploitation, and Extermination, 2d ed. [St. Lucia, Australia, I988]); F. Robinson and B. York, The Black Resistance: An Introduction to the History of the Aborigines' Struggle against British Colonialism (Melbourne, I977); Michael Christie, Aborigines in Colonial Victoria, I835-86 (Sydney, I979); Noel Loos, Invasion and Resistance: Aboriginal-European Relations on the North Queensland Frontier, I86I-97 (Canberra, I982). 
28 See especially Ann McGrath's, Born in the Cattle: Aborigines in Cattle Country (Sydney, I987); A. Pope, "Aboriginal Adaption to Early Colonial Labour Markets: The South Australian Experience," Labour History 54 (I988): I-I5; Henry Reynolds, With the White People: The Crucial Role of Aborigines in the Exploitation and Development of Australia (Ringwood, Australia, I990); Pen Hetherington, "Aboriginal Children as a Potential Labour Force in Swan River Colony, I829-I850," Journal of Australian Studies 33 (I992): 4I-55; Richard Broome, "Aboriginal Workers on South-eastern Frontiers," Australian Historical Studies 26 (I994): 202-20.

29 Beverly Nance argued that intertribal "warfare," exacerbated by European settlement, contributed more significantly to the decimation of Aboriginal populations than interracial violence. Nance, "The Level of Violence: Europeans and Aborigines in Port Phillip, I835-I850," Historical Studies I9 (I98I): $532-52$.

30 Sydney Gazette, I4 October I824; David Roberts, "Bells Falls Massacre and Bathurst's History of Violence: Local Tradition and Australian Historiography," Australian Historical Studies 26 (I995): 615-33.

3I Percy Simpson to Frederick Goulburn, 2 March I823, NSw Colonial Secretary's Papers: In-Letters (hereafter CSIL), State Records of New South Wales (hereafter SRNSW) 4/I8I8.

32 For a review of evidence for military uses of infection in the Spanish New World, see David Noble Cook and W. George Lovell, eds., Secret Judgments of God: Old World Disease in Colonial Spanish America (Norman, OK, I99I).

33 Charles Sturt, Two Expeditions into the Interior of Southern Australia during the Years I828, I829, I830, and I83I, 2 vols. (London, I833; reprint, Adelaide, Australia, I963), I:I93 [extracted in the Appendix at I829].

34 Alexander Imlay to James Bowman, 5 October I83I, CSIL 4/2IO3, SRNSW.

35 John Mair, "Observations on the Eruptive Febrile Disease Which Prevailed among Several Tribes of the Aborigines in New South Wales during the Year I830 and 3I." This report was enclosed in a letter to the NSW Colonial Secretary, dated 24 December I83I, CSIL 4/2I3O, SRNSW.

36 James Kinghorne to Alexander McLeay, 9 July I830, CSIL 4/2045, SRNSW.

37 Mair, "Observations on the Eruptive Febrile Disease," CSIL 4/2I3O, SRNSW.

38 Governor Ralph Darling instituted the annual distribution of blankets (in honor of the king's birthday) in I826 as a means of securing the protection of European life and property on the frontier by purchasing Aboriginal assistance and conciliation. M. Smithson, "A Misunderstood Gift: The Annual Issue of Blankets to Aborigines in New South Wales, I826-48," Push from the Bush 30 (I992): 73-I08. In I837, Lancelot Threlkeld and William Burton used the returns of blanket distribution to calculate a 25 percent decline in the colony's Aboriginal population over the last three years. See Threlkeld's Annual Report, I837, in Niel Gunson, ed., Australian Reminiscences and Papers of L. E. Threlkeld, 2 vols. (Canberra, I974), 2: $135-7$.

39 John Maxwell to McLeay, 29 August I829, Letters of John Maxwell, Superintendent of Government Stock, I823-3I, ed. Bertha Mac Smith and Brian Lloyd (Wangaratta, Australia, I982), I46-7. For other Wellington blanket distributions, see Gustavius Christie to McLeay, 20 April 1827, and Kinghorne to McLeay, 9 July I830, CSIL 4/2045, SRNSW.

40 For details of the compilation by Watson shortly before the Baiame waganna 
of I835, which listed seventy men with their eighty-three women and children from eleven local "tribes," see Reverend William Watson, "Return of Aboriginal Natives Taken at Wellington Valley, I834," to Col. Sec., 29 January I835, CSIL 35/IO68, SRNSW 6/6666b. Also see Table i herein.

4I The largest group ever reported by the missionaries comprised the ninety-six people, mentioned in Handt Journal, 29 December 1834, who gathered for a ceremony at Cobolyen [extracted in the Appendix at I834].

42 A figure of one-third is also proposed for the victims of the I850 epidemic of smallpox among the Bungyarlee and Parkungi tribes of the River Darling in western NSw by Frederick Bonney, an early settler, based on his conversations with survivors. See Bonney, "On Some Customs of the Aborigines of the River Darling, New South Wales," Journal of the Anthropological Society (U.K.) I3 (I884): I23.

43 Handt Journal, 4 November I835, comments on the low number of children in large congregations.

44 Michael Pearson estimated what he calls the Wellington "clan grouping" to have numbered about eighty people, basing his figure on the postepidemic population suggested by the journals and lectures of the missionary James Günther. Pearson, "Seen through Different Eyes: Changing Land Use and Settlement Patterns in the Upper Macquarie River Region of Nsw, from Prehistoric Times to I860" (Ph.D. diss., Australian National University, I98I), 72. The problems associated with assessing populations on the basis of the failure of the Wiradjuri to recover demographically mirrors that of Native Americans reviewed by Russell Thornton, Tim Miller, and Jonathon Warren, "American Indian Population Recovery Following Smallpox Epidemics," American Anthropologist 93 (I99I): 28-45.

45 For the importance of taking account of demographic recovery when assessing pre-epidemic populations, see Thornton et al., "American Indian Population Recovery."

46 Handt could not convince the girl to leave the hut keeper. Handt Journal, I3 December I832 [extracted in the Appendix at I832].

47 According to Watson, Kobohn Bobby was "always in the bush" and had two wives, two boys ten or twelve years old, and a young child one-and-a-half years of age. Watson Journal, 20-2I April I833.

48 The major descriptive ethnography is A. W. Howitt, The Native Tribes of South-east Australia (London, I904; reprint, Canberra, I996), though W. E. H. Stanner considers it "not his best memorial." See entry by Stanner, Australian Dictionary of Biography (Melbourne, I85I-90), 434. For a list of Howitt's many papers, see Mary Howitt Walker, Come Wind, Come Weather (Melbourne, I97I), 3I3-9; Howitt can be supplemented by R. H. Mathews, some of whose papers are re-edited by Janet Mathews, comp., The Opal That Turned into Fire, ed. Isobel White (Broome, Australia, I994). Major studies by Ronald and Catherine Berndt on southeastern religious beliefs include: R. M. Berndt, "Wuradjeri Magic and Clever Men," Oceania I7, no. 4 (I946-7): 60-86; no. I8 (1947-8): 327-65 [Klaus Reprint, Nendeln/Liechtenstein, I97I]; Berndt, Australian Aboriginal Religion (Leiden, I974); R. M. Berndt and Catherine Berndt, with John E. Stanton, A World That Was: The Yaraldi of the Murray River and the Lakes, South Australia (Melbourne, 1993).

49 George Bennett, Wanderings in New South Wales (London, I834), 2 vols., I: I48, 
I54 [extracted in the Appendix at I83I]. Campbell also notes dunnerh dunnerh brought by "Wundah," citing K. Langloh Parker, The Euablayi Tribe (London, I905), 39.

50 Hale records from Wellington the "absurd idea" "that no person dies a natural death. If a man perishes of disease at a distance from his friends, his death is supposed to have been caused by some sorcerer of another tribe, whose life must be taken for satisfaction." United States Exploring Expedition during the years I838, I839, I840, I84I, I842 under the command of Charles Wilkes, vol. 6, Ethnography and Philology, by Horatio Hale, philologist of the expedition (Philadelphia, I846; reprint, Ridgewood, NJ, I968), II5. For Wiradjuri concepts of illness, see Berndt, "Wuradjeri Magic," 60-86; Berndt, Australian Aboriginal Religion, 306.

5I See Nance, "Level of Violence."

52 Bennett, Wanderings in New South Wales, I:I53 [extracted in the Appendix at I83I].

53 Campbell, "Smallpox in Aboriginal Australia I829-3I," 556.

54 Wellington Valley was first established as a depot in preparation for Oxley's I8I8 expedition down the Macquarie River. From I823 it accommodated remote government agricultural and stock stations, manned by around eighty convicts, and several private stock-stations.

55 Bennett, Wanderings in New South Wales, I: I48 [extracted in the Appendix at I83I].

56 George Busby to James Bowman, I9 October I832, 3I/93I6, 4/2I30.

57 For the account published by lay missionary John Harper in I825, see note I6 above.

58 John Henderson, Observations on the Colonies of New South Wales and Van Diemen's Land (Calcutta, I832).

59 The bird called the "eaglehawk," now known as the wedge-tailed eagle (Aquila audax), is distributed throughout Australia. With a wingspan of two meters it is one of the largest eagles in the world. See also note $\mathrm{I} 20$ below and the Appendix, at Mudjegong (including note c) and at I830.

60 See Swain, A Place for Strangers, I33-9.

6I Bennett, Wanderings in New South Wales, I:I53 [extracted in the Appendix at $\mathrm{I} 83 \mathrm{I}]$.

62 Ibid., I:I55-6.

63 The originals are held as part of the CMS archives. Most of the papers relating to the Wellington mission were microfilmed as part of the Australian Joint Copying Project miscellaneous series. However, microfilming proceeded prior to the reordering of the papers by Rosemary Keen, for which see her unpublished "Catalogue of the Papers of the Missions of the Africa (Group 3) Committee,” vol. 7, New Zealand Mission, I98I, CMS. Based on the reordered papers in Birmingham, the bulk of the missionary journals and correspondence, with other supporting information, has been developed into an ongoing electronic edition accessible on the Internet, see Hilary M. Carey and David Roberts, eds., "The Wellington Valley Project," available on-line at www.newcastle.edu.au/discipline/history/wv-project/index.html. Shelf marks have been omitted from citations to CMS Wellington mission records but may be recovered by referring to the electronic edition.

64 For the Wiradjuri war, see Read, A Hundred Years War. For the Wellington 
mission, see papers by Jean Woolmington especially, “Writing on the Sand': The First Mission to Aborigines in Eastern Australia," in Aboriginal Australians and Christian Missions, 77-92. For the overall context of mission activity in southeastern Australia, see Hilary M. Carey, "'Attempts and Attempts': Missions to Australian Aborigines in Colonial Australia," in Mapping the Landscape: Essays in Australian and New Zealand Christianity: Festschrift in Honour of Ian Breward, ed. Susan Emilsen and William W. Emilsen (New York, 2000).

65 Sydney, Mitchell Library, Günther Papers: Correspondence [AI45O]; Lectures and Sermons [B503]; Journals [B504]; Papers on the Wiradjuri Dialect [B505]; Mitchell MS B504 contains Günther's own copy of the journal he maintained from $1836-1840$, in I84I, and in I865.

66 Although he later claimed otherwise. See introductory note to circa 1860 in the Appendix.

67 Carey and Roberts, eds., "Wellington Valley Project."

68 Watson Journal, 5-6 October I833 [extracted in the Appendix at I833].

69 "Corrobborree," meaning a dance ritual, is a word from the Sydney Cove language, which quickly became creolized, as Howitt noted in Native Tribes, 4I3.

70 Watson Journal, 22 April I834 [extracted in the Appendix at I834].

7 I Ibid.

72 See note I2I below for the burbung.

73 Watson Journal, I7 May I834 [extracted in the Appendix at I834]; also see note 4 above.

74 This is possibly the site described by Henderson, Observations on the Colonies, I47, which included an extensive grove of totemic trees or dendroglyphs.

75 Handt Journal, 29 December I834 [extracted in the Appendix at I834].

76 Watson frequently reports making gifts of meat to parties of Aborigines in order to encourage them to remain close to the mission. On 9 May I835, he notes that he had cut up from sixty to seventy pounds of beef for a party of sixteen young men and on II May I835, lamenting the high cost of provisions: "It is a hard thing to say to a native, 'I cannot afford to give you bread.' "Watson Journal, 9 and II May I835. On 22 December I835 he gave a party of seventy natives a five-hundred-pound bullock [extracted in the Appendix at I835].

77 James Günther, "Lectures on Aboriginal People of Australia," Sydney, Mitchell Library, MS Z B505, p. II3, notes in connection to the preparation of a burial area: "They used hoes, spades and borrowed from the Missionary Station. With their original tools, it would have taken them much more time to finish the grave."

78 Günther "Lectures on Aboriginal People of Australia," pp. I5-I6 [extracted in the Appendix at circa I860].

79 Berndt, "Wuradjeri Magic," 330-I, and references to Howitt in Berndt's note 7 .

80 Watson Journal, 9 February I835; Handt Journal, I5 February I835.

8I Watson Journal, 9 February and 23 February I835; Handt Journal, 30 February 1835 .

82 Handt Journal, I4 March I835.

83 Handt Journal, 9 April 1835 .

84 Watson Journal, 20 March and 28 March I835.

85 Watson to Richard Hill, 25 March I835 [extracted in the Appendix at I835].

86 Watson Journal, 28 March I835 [extracted in the Appendix at I835].

87 The Mulunga was first reported by Walter Roth in the I89os and spread 
rapidly throughout much of pastoral Australia. For a review see Kolig, "Religious Movements," I65-7. Adopting a characteristically extreme position, Swain argues that the Mulunga was largely millennialist in nature and, despite a dearth of supporting historical evidence, that it was sparked initially by the resistance to European occupation led by Djandomarra/Pigeon in northern Queensland. See Swain, A Place for Strangers, 219-33. As Kolig, "Religious Movements," I66, points out, the Mulunga was not perceived as too anti-European prior to the insightful reports by the missionary Otto Siebert, "Sagen und Sitten der Dieri und Nachbarstämme in Zentral-Australien," Globus 97 (I9I0): 53-59. It is possible that not all manifestations of the dance were anti-European in character.

88 Watson Journal, 6 April I835 [extracted in the Appendix at I835].

89 Watson Journal, 28 March I835 [extracted in the Appendix at I835].

90 Ibid.

9I Günther, "Lectures on Aboriginal People of Australia" [extracted in the Appendix at circa I860].

92 Watson Journal, 24 April I835 [extracted in the Appendix at I835].

93 Watson Journal, 6 April I835 [extracted in the Appendix at I835].

94 Bennett, Wanderings in New South Wales, I:I54 [extracted in the Appendix at I83I].

95 Thornton, We Shall Live Again.

96 Watson Journal, I7 October I835 [extracted in the Appendix at I835].

97 In his "Return of Aboriginal Natives Taken at Wellington Valley, I834," pp. 2I2-3, Watson profiles Gentleman Jackey as follows: "English Name: Gentleman Jackey; Native Name: Mooinba; Probable Age: 40; Number of Wives: 6; Children: o; Designation of Tribe: Wellington; Place of District or Usual Resort: Wellington Valley.”

98 Handt Journal, I5 February I835.

99 Watson Journal, 6 April I835 [extracted in the Appendix at I835].

Ioo Ibid.

Ior Handt Journal, 23 April I835; Watson Journal, 24 April I835 [both extracted in the Appendix at 1835$]$.

IO2 Ibid.

I03 Hale, Ethnography and Philology, IIo [extracted in the Appendix at I838].

IO4 Watson Journal, I7 October I835 [extracted in the Appendix at I835].

I05 Watson Journal, 3 September I835. Watson noted that his burial seemed to contravene the usual customs. Young men and women were present together, and he was laid to rest prone rather than being interred in a sitting position.

Io6 Watson Journal, 29 December I835 [extracted in the Appendix at I835].

I07 Watson Journal, I4 October I835, CMS CN/093: “[Kabbarrin] is very unwell but when I began to address the natives, he usurped me, and talked to them on the subject of religion in a manner that truly astonished me." And again on I7 October I835: "Had some conversation with the natives here this evening; as usual Kabbarrin was the chief speaker."

I08 Patricia Grimshaw et al., Creating a Nation, I788-I990 (Ringwood, Victoria, Australia, I994), I3I.

Io9 McGrath, Born in the Cattle, 68-94. See also McGrath, "The White Man's Looking Glass: Aboriginal-Colonial Gender Relations at Port Jackson," Australian Historical Studies 24 (October 1990): 189-206.

IIo Watson Journal, 27 August I833 [extracted in the Appendix at I833]. 
III Watson Journal, 8 December I835 [extracted in the Appendix at I835].

II2 Howitt, Native Tribes, 740-I.

II3 Watson Journal, I9 December I835 [extracted in the Appendix at I835].

II4 Watson Journal, 29 December I835 [extracted in the Appendix at I835].

II5 For a brief overview, see R. M. Berndt and Catherine H. Berndt, The World of the First Australians, 5th edition (Canberra, I988), chaps. 7-8.

II6 Handt Journal, 8 September I834; or Watson Journal, 23 September I 835: "The natives were singing their lewd songs till very late last night."

II7 Watson Journal, 8 May I835 [extracted in the Appendix at I835].

II 8 For the power of the clever men as remembered by informants in I943, see Berndt, "Wuradjeri Magic," esp. 334-7 (on how Baiame gave power to the clever men). Terms for the Wiradjuri clever men are listed on p. 33I.

II9 There is additional evidence for this in the derivation of the two names. According to Watson, Tharrawiirgal has his name from a large tree growing out of his thigh and which is the basis of his name from Tharra "thigh" and Wiirgal "a cutter of wood" (Watson Journal, 6 April I835 [extracted in the Appendix at I835]). According to Janet Mathews, the name Daramulun was derived from dharru "thigh" and mulun meaning "one side." See Mathews, The Opal That Turned into Fire, 93-94.

I20 Gunson, Australian Reminiscences, I:3, notes that a metamorphic relationship appears to exist between the southeastern sky heroes and the eaglehawk, which was often the totem of the dominant class in many tribal structures, as well as having significance in Aboriginal cosmology as the bright star Altair.

I2I For descriptions of Wiradjuri initiation ceremonies before the complete collapse of traditional life, see A. W. Howitt, "On Some Australian Ceremonies of Initiation," Journal of the Anthropological Institute (U.K.) I3 (I883-4): 43259; R. H. Mathews, "The Burbung, or Initiation Ceremonies of the Murrumbidgee Tribes," Journal and Proceedings of the Royal Society of New South Wales 2I (I897): iii-53; Mathews, "The Burbung of the Wiradthuri Tribes," Journal of the Anthropological Institute (U.к.) 25 (I896): 295-3I8; 26 (I897): I72-85; and subsequent papers by both authors listed by Berndt, "Wuradjeri Magic," 329, note 5. Also Howitt, Native Tribes, 583-8; and Berndt, Australian Aboriginal Religion, 27-30.

I22 Berndt, Australian Aboriginal Religion, 27-28; Howitt, Native Tribes, 585.

I23 K. Langloh Parker, comp., and Henrietta Drake-Brockman, ed., Australian Legendary Tales (London, I896), I5-24; Parker, Euablayi Tribe.

I24 Berndt and Berndt, $A$ World That Was, 240-2.

I25 See R. H. Mathews I898, I899, I908 as compiled by Janet Matthews, The Opal That Turned into Fire.

I26 Hale, Ethnography and Philology, Iıо-г.

I27 Günther's word list lists three different Wiradjuri words to which he gives the English meaning "tomahawk."

I28 In Mathews, "Burbung of the Wiradthuri Tribes," 300.

I29 Howitt, "Some Australian Ceremonies," 442.

I30 Janet Mathews, The Two Worlds of Jimmie Barker (Canberra, I977), 70-7I.

I3I Parker, Australian Legendary Tales; R. H. Mathews, Folklore of the Australian Aborigines (Sydney, I899).

I32 See Berndt, Australian Aboriginal Religion, fig. 5I, for a photograph of the sacred tree marked by the three-clawed foot of Eaglehawk being climbed by 
a clever man during the bora ceremony. For "Baiamai's Fire," which was kept constantly burning during the burbung, see Mathews, "Burbung of the Wiradthuri Tribes," 300.

I33 Kolig, "Religious Movements," I66, notes that the phenomenon of wandering cults is "entirely traditional" and cannot be seen as the consequence of European contact.

I34 Hale, Ethnography and Philology, IIo [extracted in the Appendix at I838].

I35 Ibid.

I36 Howitt, Native Tribes, 4I3-6.

I37 Günther, "Lectures on Aboriginal People of Australia," I09-I6 [extracted in the Appendix at circa I860]; Watson Journal, 24 April I835 [extracted in the Appendix at I835].

I38 Howitt, Native Tribes, 4I6. John Bulmer was at this time an Anglican missionary at Lake Tyers in eastern Victoria.

I39 Berndt, "Wiradjuri Magic," 344-50.

I40 Ibid., 347 .

I4I Gunson, Australian Reminiscences.

I42 Howitt, Native Tribes, 496-7.

I43 See note u of the Appendix.

I44 Koepping, "Nativistic Movements," 397-4II. 